\title{
El Perú en la liferafura de viaje europea de los siglos XVI, XVII y XVIII
}

Relaciones de Corsarios y Pirałas

Por Edgardo Fivera Maftínez

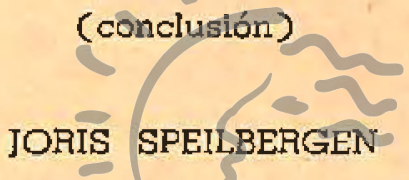

La relación de la expedición holandesa de Joris van Speilbergen al Pacífico Sur (y de la circumnavegación de la tierra que efectuó luego), se publicó en Leyden, 1619, en holandés. Esta edición original conteníchuna dedicatoria del libró alos Estados Generales, firmada por el mismo Speilbergen, $y$ cuyg lectura no deia ninguna vacilación en cuanto a la identidad del aulor, que es, precisamente, Speilbergen. Esta dedicatoria no fue reproducida por las posteriores ediciones en lenguas extranjeras, que fueron las que consultaron editores y estudiosos, por explicables razones linguísticas. Esta circunstancia, unida a ciertos descuidos y omisiones de los cuales de Villiers -en su edición del este libro para la Hakluyt Society- hace responsable a Renneville, dieron lugar a un difundido error que señalaba a un tal Jean Cornelius de MaYz como autor del diario de viaje, error que después fue involuntariamente continuado por Burney, Callander, Camus, y hasta Tiele. Una intormación bibliográfica detallada se encontrará en el estudio que figura en la edición de de Villfers, y loumbién en Tiele.

Esta relación no nos ofrece material de mucho interés para nuestro propósito. Se explaya más bien en la historia interna de la expedición, en los relátos de batallas, etc. Apenas si hemos hallado esta breve descripción de Arica, harto lacónica: 
Den 2. zün op met boo spoedigen windt tegens den abondt ghehomen boo boors Stedehen Ariqua gelegen op 18. graden ende 40 . minuten. Op d'eezüde van dit Stedehen sietmen eenen hoog verpeden bergen en op den af-hanck den seiben een breet dorp beset zünde met bele hupfen ende op d'andere zuide eene groene Plaisante ploetse beplant zinde met alderhen soorten van Boomen als onder anderen van cítroener ende Orangie-Appelen ${ }^{62}$.

[E] 2 de Julio llegamos, con viento Iavorable, hacia el atardecer, a lo largo del mencionado pueblo de Arica, situado en $18^{\circ} 40^{\circ}$ de latitud $A$ un lado de esta aldea se halla una alta montaña, y en el declive de la última un pueblo amplianente extendido, el cual consiste en muchas casas, y en el otro lado un sitio placentero y verde, plantado con toda clase de árboles, entre otros, limones y naranjas].

Huarmey les produjo una grata impresión, pues reunia una agradable situación, un buen puerto y agua fresca:

Desde plaetse van Guarme is seer schoon ende plaisandt heft eene grodte encle wel gelegene Haven daer men met veele schepen mach leggen. Daet is ook eene staende Poel met versch water daer op provisie deden ${ }^{63}$.

[Esta ciudad de Huarmey es muy hermosa $Y$ agradable, y tienøo ure puertonmuycarazide $Q y$ bien situado, en el cual pueden estar muchos buques. Hay también una constante laguna de agua fresca, de la cual nosotros nos aprovisionamos].

Del puerto de Paita nos dice que era

eene schoone bequame Faven op de Stadt Peyta... ${ }^{B 4}$.

[un hermoso, bien situado puerto cerca a la ciudad do Paita].

Sus iglesias, su claustro. y otros edificios también eran "schoone":

62.-En HARTGERS, Ioost: "Oost-Indische Voyagien Door dien Begin en Voortgangh. ..", Amsterdam, 1648, p. 35.

ta. -Id. Id., p. 44.

64.-Id., Id., p. 45. 
Marer inne waren gheweest twee Kerchen een Klooster, ende veele schoone andere chebouwen ende hursinghen ${ }^{n \pi}$.

[En ella -en Payta-, había dos iglesias, un claustro, $y$ otros muchos hermosos edificios $y$ moradas].

En la Isla de Lobos sus hombres capturaron dos pújaros de "wonderbaren groethept", con picos, alas y garras como de dgulla, un cuello como de oveja, y crestas en la cabeza, y formados en, "een seer wonderlü maniere".

\section{IACQUES L'HERMITE}

En 1626, en Amsterdem, apareció una relación de la expedición de Jacques L'Hermite a las costas de las colonias espaĩolas del Pacífico Sur - a lo largo de las cuales navegaron en el año de 1624-, de la que es probablemente autor, según la opinión de Tiele, Johannes Walbeeck, "matemático" de la flota. La edición clemana de Estrasburgo, 1629, ha sido atribuida a Adolf Decker. El diario revela "la main d'un homme instrit, observateur exercé et sachant communiquer ses observations" (Tiele). No hemos encontrado en él ninguna observación que nos plieda ser de utilidad. Una versión figura en Callander vol. I.

\section{LOS FILIBUSTEROS DEL PACIFICO}

Son designados de este modo - por Burney y otros autores-. los filibusteros que, cruzando el istmo de Panamá, ingresaron al Pacítico para atacar, principalmento, las costas del Perú y Chtle, y el comercio marítimo que por sus puertos se efectuchba. Sus incursiones más notables tuvieron lugar entre 1680 y 1688 (sobre todo las efectucdas por los que constituím el grupo del "Saríisima Trinidad"). La historia de sus expediciones es extremadamonte compltcada y confusa, a pesar de que se conservan varias relaciones de ellas. Es por esto que no podremos examinarlas en el arden cronológico que hasta ahora hemos seguido, sino en el sigulente: Dampier, Cowley, Wafer, Funnell, Raveneau de Lussan, Ringrose, Sharp.

65.-Id., Ic., p. 46 . 


\section{WILLIAM DAMPIER}

Nacido en Easł Coker, en 1652, William Dampier se distingue de entre todos sus camaradas "de armas" que se aventuraron por las aguas de las colonias españolas del Pacífico, no sólo por la justa celebridad que ya desde su época le granjearon sus escritos, sino también por su curiosiciad, su inteligencia, su extraordinario espiritu de observación. su cultura y sus escasas y negativas dotes de mando. Es con cierta reticencia que lo incluímos en esie estudio sobre las relaciones de corsarios y piratas -habría que incluirlo también en un trabajo sobre los viajeros científicos que han estado en el Perú. Si "profesionalmente" estaba dentro de la piratería - lo cual, dentro de las circunstancias de nacionalidad $y$ época en que vivió, no tenía un carácter necesariamente deshonroso-, su vocación y el verdadero trabajo de su vida fueron la hidrografía, la navegación. la meteorología, $Y$, en suma, el ejercicio $y$ satisfacción de su espíritu fundamentalmente curioso. En 1697 salió a luz la relación de su "A New Voyage round the world, describing particulary the isthmus of América, several cocsst and islands in the West Indies, the isles of Cape Verd, the passage by Tierra del Fuego, the South sea coasts, Chili, Peru and Mexico". Londres. Fue un verdadero éxita de librería, que le movió a publicar un segundo volumen, que comprendía la relación de su viaje de Achen a Tönquíz y Madras sus primeras qventuras en Campeche $Y$ "A Discourse of the Trude Winds". Excelentes referencics bibliográficas "Iobre Pascmiltipleso edicishes de Dampier se encuentran en Sabin. ("Dictionary of Books relating to America"). Stevens, citado por ésle, menciona una edición de 1729 como la más recomendable, a pesar de sus deficiencias e interpolaciones. Nosotros hemos manejado la edición en dos volúmenes de 1699 , de los cuales el primero reproduce fielmente el texto de 1677 , con varicciones $\sin$ importancia.

Todos estos bucaneros y piratas, acostumbrados al perfil chato y monótono de las costas de Europa, o al perfil un poco más elevado de las Indias Occidentales y la América Central, debieron de sorprenderse de la yran altura de las montaños, que, en los días claros, veían a lo largo de las costas de Chile y del Perú. Dampier es de ellos:

All this course of the Land, both of Chili and Peru is vastly high... The Land (especially beyond this, from 24 
deg. s.). Lal. 17, and from it to 10 [zacaso las Cordilleras Blanca $y$ de Huayhuash?] is of $\alpha$ most prodigious height ${ }^{\mathrm{es}}$.

Estos adjetivos, "vastly", "prodigious", tienen en nuestro autor su más viva y original intensidad semántica, pues no es hombre acostumbrado a las calificaciones líricas, y no abandona fácilmente la objetividad de su lenguaje para expresar sentimientos que, acaso, desconocía su naturaleza, al parecer no particularmente dotado de sensibilidad "poética". Continúra, pues, diciendo:

It lies generally in Ridges parallel to the shore, and 3 or 4 Ficiges, one with another, each surpassing the other in height; and those that are farthest within Land, are much higher thon others ${ }^{T}$.

En las líneas que siguen deseariamos ver un sentimiento del color, por leve que fuese, y no sólo la concreta observación de un fenómeno:

They always [esas montañas] appear blue when seen at Sea: sometimes they are obscured with Clouds, but no so often as the high Lands in other parts of the World, for here are seldom or never any Rains on these Hills, any more than in the Ser near it neither gre they subject to Fogis.

\section{"Jorge Puccinelli Converso"}

Y termina el pórrafo comparando estas montañas con el Pico de Tenerife, que por entonces ara tenido como uno de las más elevadios del mundio:

These are the highest mountains that ever I saw far surpassing the Pike of Tenerife, or Santa Martha, and I Believe any mountoins in the Worldo".

También en su "A Discourse on the Trade Winds" insiste en la gran altura de los Andes:

66.-William DAMPIER, Op. Cit., p. 94.

67.-Id., Id., p. 95.

68.-Id. Id., p. 94.

69.-Id. Id., p. 94 
'tis known that the Andes in America are some of the highest Mountains in the World, but whether there are any on Continent of Africa in those Latitudes so high, I know not. the I have not heard of any, at least none such are visible to Seamen ${ }^{70}$.

$Y$ en el mismo tratado otribuye a esa excesiva altitud la ausencia de lluvias en la costa. De Paita nos da esta breve descripción:

Payta is a small Spanish Sea-Port Town the lat. of 5 d. $15 \mathrm{~min}$. It is built on the sand, close by the Sea in a nook, elbow, or small Bay, under a pretty high Hill. There are not above 75 or 80 Houses, and two Churches. The houses are but low and ill built ${ }^{71}$.

Y continúa luego con una descripción de los modos de construlr -esto es, de levantar paredes - en la costa peruana. Y es sólo a propósito de la falta de materiales de construcción en ella que nos dice algo de su aspecto:

This dry Country commences to the Northward from about Cape Blanco to Coquimbo, in about $30 \mathrm{~d}$. S. having no Rain that I could ever observe or hear of; nor any green thing growing in the Mountains: neither yet in the Valleys, except where here and there water'd with a few small Rivers desper'd up and down ${ }^{72}$.

De los interiores dejlas casasmel que debeshaberlos conocido en sus desemarcos, aunque no en Lima - guarda el recuerdo de su suntuosidad un poco exótica:

The Inside of the houses are hung round with rich embroldered, or painted Cloths. They have likewise abundance or fine Pictures, which adds no small ornament to their Houses: these. I suppose, they have from Old Spaln $7 s$.

Las Iglesias de Paita "were large and fairly carved", pero las casas no estaban amobladas con el lujo de aquéllas que acaba de decir.

70.-Id. Id., vol. II, p. 78.

71. Id. Id., vol. I, p. 139.

72.-Id. Id., vol. I, p. 140.

73.-Id. Id., p. 140. 
A propósito de la playa de Paita y de las Islas de Lobos se extiende en largas indicaciones náuticas, que no ofrecen ningún interés, salvo el técnico.

Cerca de Paita, a unas leguas, habia -o hay - una aldea de pescadores, que por entonces solía ser visitada de piratas y corsarios en busca de agua y provisiones. Dampier estuvo en ella, y le debemos una descripción muy minuciosa de las embarcaciones de que sus habitantes se servian para la pesca o para sus viajes a Guayaquil y Panamá, descripclón que, además de su principal interés náutico, nos da muestra de esa suerte de interés "etnológico" del cual Dampier a menudo nos ofrece ejemplos, pero que se manifiesta sobre todo en los relatos de sus viajes por las islas de Oceania y los países de Asia, que le llamaron más vivamente la atención, en éste como en otros órdenes de cosas ${ }^{74}$.

Como vemos, es muy difícil hallar en Dampier una reacción personal, emotiva, frente al paisaje, a la leyenda, a las cosas del Perú; no son en ningún momento motivos en su obra, no obstante que una actitud sensible frente a ellos no está en contradicción con la objetividad y exactitud científica (plénsese en Humblodt). No olvidemos que escribió sus observaciones en circunstancias por lo menos difíciles, en medio de las mayores incomodidades, - para proteger sus manuscritos los guardaba dentro de una caña de bambú- lo cual le obligaba, ciertamente, a no anotar sino aquello que consideraba esencial desde su punto de vista científico, náulico, geográfico. Sus observaciones son, antes que nada, producto de su extremada $y$ vighante cufiosidad intelectual, sensible y dirigida casi exclusivamente a lo concreto, a los fenómenos naturales, objetivos. Dampier está igualmente lejos de la abstracción y el placer de la hipótesis pronta y gratuita como del gusto por lo maravilloso. Y sin embargo, a pesar de su indiscutible talento para realizarlas y registrarlas, "Experience and observation he neves elevated into a system, but to bring the method of science into nautical discovery was signifiant not alone for the exploration of the Pacific but of the whole unknown world" (Beaglehole) ${ }^{76}$. Esto es explicable, aunque no fuera más que por la agitada existencia de pirata que llevó -y de la cual dice tan poco, que bien pudiera creerse que el único objeto de las expediciones en que

74.-Id. Id., pp. 141-142.

75. J. BEAGLEHOLE: "The Exploration in the Pacific", 2da. edición, Londres, 1947, p. 212. 
tomaba parte era exclusivamente científico y geográfico, y no pirático, como era en realidad.

Sus observaciones están escritas en un estilo preciso, y aun vívido, dentro del carácter de objetividad y economía que le impine la naturaleza y el motivo de ellas - "for I am persuaded, that if what I say be intelligible, it matters not greatly in what words it is expressed"ie. A pesar del aparente desorden de las mismas, hay en ellas una coherencia interna elemental, que, en cierta medida, concilia la imprevisibilidad de las experiencias y las exigencias de la realidad inmediata. La adjetivación casi nunca se aparta de una estricta fidelidad a lo observado y a su carácter de hecho externo y objetivo. Es un estilo agradable, de fácil lectura: "in their clear, easy, homely, common-sense style, his writings are almost classical"'77.

\section{COWLEY}

De las expediciones de los filibusteros del Pacífico tenemos otra relación escrita por el Caplán Cowley -hombre de viva inteligencia y excelentes cualidades de piloto-, el cual participó en ellas contra su voluntad, pues no le dijeron el verdadero objeto que se proponían. Hemos consultado la versión que de aquélla aparece en Harris yol. Io tela única que nos ha sido accesible, pero no hemos encontrado ningún pasaje que nos interese.

\section{FUNNELL}

De la misma expedición en que tomó parte Dampier y que. partiendo de Inglaterra en Agosto de 1685, capturó un buque danés al que luego pusieron por nombre "Bachelor's Delight", $\theta$ incursionó después por las costas del Pacífico, tenemos una relación escrita por Funnell, en la cual éste se refiere con muy poco calor a Dampier. De ella sólo hemos podido encontrar la versión que aparece en Callander, vol. III, "Voyage of Funnell to Magellanica". Nos ofrece solamente dos referencias que nos pueden ser útiles:

76.-DAMPIER, Op. Cit., vol. I, Prefacio, p. $s / n$.

77.-J. K. LAUGHTON, en el artículo correspondiente a Dampier en el "Dictionary of National Biography". 
The land continues [desde Coquinmbo hacia el Norte] very hiagn and montainous; so that, I think, it is the highest land I ever sawir.

At this island [la isla del Gallo] you may see the main land, which is very low near the waterside, but prodigious high up in the country ${ }^{79}$.

Este diario nos muestra un hombre de entendimiento claro y seguro, y de curiosidad atenta y despierta.

\section{RAVENEAU DE LUSSAN}

Debemos a Raveneau de Lussan un excelente documento sobre una expedición a las costas del Pacífico que tuvo lugar entre 1684 y 1688 ("Journal du Voyage fait à la Mer du Sud avec les Flibustiers de l'Amérique". París, 1689). Estuvo entre los filibusteros que, cruzando el istmo de Panamá, se unieron a los compañeros de Sharp. que todavía operaban en esos lugares e infestaron por un tiempo este litoral. Chinard pone a Raveneau de Lussan como un ejemplo de aquellos aventureros que partían a América sin "aucun désir de faire oeuvre durable, ou même de s'enrichir..." "mais pour employer un surcroît de forces, par pur amour du danger et. si parfois, Cls sont un peuS romantiques et pompeux, au moins lour bravoure n'est pas feinte" (L'Amérique et le rêve éxotique"). A pesar de lo que puede haber de convenclonal en este concepto, estas palabras contienen todorvía bastante de verdad. La relación de Lussan está agradablemente escrita, con bastante fluidez y sentido de lo cómico. A través de su esthlo $y$ de las cosas que cree dignas de ser contadas al lector, se advierte a un hombre fuertemente inclinado a la acción, a la aventura.

Es uno de los filibusteros que más expresamente da testimonio de la riqueza y abundancia en todas cosas del Perú:

Avant que de quitter cette côte je ne puis me dispenser de dire, que le Pérou est un des riches païs du monde.

78.-John CALLANDER: "Terra Australis Cognita, or Voyages to the Terra Autralis", Edimburgo, 1766-68, vol. III, p. 154.

79.-Id. Id.. p. 156. 
non seulement par la quanlité d'or et d'argent que les Espagnols tirent des mines qu'ils y possedent; mais de plus par la grands fecondité de la terre qui rend à ceux qui la caltivent trois recoltes par chacune année, tant de bled que de vin, \& qu'outre las fruits qui sont particuliers à toute l'A. mérique. ils en ont encore beaucoup de ceux qui croissent en France. De sorte que cette grande diversité d'especes fait qu'en toutes les saisons de l'année on en trouve loujours de frais $^{\text {B0 }}$.

$Y$ en otro lugar leemos:

L'abondance de ce riche métal [la plata] le rend si commun dans ce pays, que la plupart des choses que nous faisons en France, d'acier, de cuivre \& de fer, ils les font avec l'argent: cette indifference que nous temoignions en avoir, donnoit souvent occasion à leurs gens mêmes de se mêler avec les nôtres, pour piller et butiner sur leurs propres concitioyens, celuy que nous negligions, dont ils n'étolent pas si dégoutez gúe nous, ou pour mieux dire si embarrassez à le transporter, étant dans leur pais, \& nous fort loin du nôtre ${ }^{B 1}$.

Esta constatación se sitúa en la tradición de la leyenda dorada del Perú, y nos figuramos bien la impresión que debió producir en sus lectores europeos de aquel tiempo.

De las llamas nos cuenta, con simpática credulidad, que suo len arrodillarse anuy mansamente cuăndos se les quiere cargar, asi como cuando llegan al lugar adonde se las conduce, con el mismo "Instinto" que los camellos. De su descenso a Guayaquil - ciudad que tomaron y saquearon-conserva el recuerdo de sus mujeres, "parfaitement belles", y de la extraordinaria licencia en que vivían frailes y monjas.

\section{BASIL RINGROSE}

Este filibustero vino a América hacia 1679, y tomó parte en el saqueo de Santa María, y más particularmente en los ratds

80.--RAVENEAU DE LUSSAN: "Journal du Voyage fait à la Mer du Sud avec les Flibustiers de l'Amérique", Paris, 1689, p. 336.

81.-Id. Id., p. 335 . 
electuados a lo largo de la costa del Pacífico Sur por Harris, Coxon, y Shorp — sobre todo a órdenes de éste último. Llevó de estas expediciones una relación borstante cuidadosa y detallada, que no sólo da cuenta, objetiva y escuetamente, de los hechos, sino también de la historia interna de esas "empresas". Contiene también su relato algunas breves descripciones de los lugares "visitados", de los nativos con los cuales trataron, cartas de los puertos y de las costas, etc., aunque sin liegar, nt con mucho, a la rtqueza informativa de un diario como el de Dampier. Fue publicada en Inglaterra en el año de 1865, como parte de la "History of the Bucaneers". Regresó a América en 1684, en el "Cygnet", y murió a manos de los españoles en las costas de Méjico, en 1686. El diario de Ringrose es sobre todo una crónica del tiempo atmosférico, de las distancias recorridas, de los vientos - cosas que registra con sequedad técnica. Sus observaciones sobre las disputas y querellas de la tripulación de su buque están escritas en un lenguaje bastante preciso, que a veces revela una cierta rapidez y agudeza en la apreciación de los caracteres. Los dibujos con que acompaña su relación tiene un interés puramente náutico, y parecen servir, antes que nada, al propósito de hacer reconocibles los diferentes puntos y accidentes de las costas observadas. Un manuscrito de esto diario, con apreciables variantes con respecto a la relación impresa, y con hermosos dibujos y cartas por el Capitán William Cook, se encuentra en elMuseo Británico (Sloane MS 48), según Elliot Joyce.

"Jorge Puccinelli Converso"

Su descripción de Paita es típica del estilo comúnmente empleado por esta literatura:

The town of Paita itself is situated in a deep Bay, about two Leaques to Leeward of this Hill. It serves for an Embarcadero, or Port Town, to another great Place which is distant from thence about thirteen Leagues higher in the Country, and is called Piura, sited in a very barren Country ${ }^{82}$.

Su referencia a la altura de los Andes no puede ser más lacóntca y neutra:

82.-RINGROSE, Basil, "The Dangerous voyage and bold attempts of Capt. Barth. Sharp, Watlin, Sawkins, Coxon, and others", en OEXMELIN: "The History of the Bucaneers of America", Londres, 1699 , p. 65 . 
We saw all along as we went very high Land, covered with Clouds, insomuch, that we could not see its top ${ }^{89}$.

Su descripción de Ilo es igualmente corta y objetiva:

We found it very pleosant, being all over set with Fig-tres, Olive-trees, Orange, Limon, and Lime-tres, with many other agreable fruits $^{84}$.

La de Arica revela su interés por lo que tenía relación con sus actividades "profesionales":

The Houses of this Town of Arica are not above Eleven Foot hight, as being built of Barth, and not of Brick or Timber. The Town itself is foursquare, and at one corner stands the Castle, which may be easily commanded even ne squroit voir la terre qu'à deux ou trois Lieuës de dis-

Más adelante vuelve a dar otra rápida descripción de Paita, y otra de Colón, de interés aún menor.

\section{BARTHOLOMEW SHARP}

Fue óste uno de los-más "conspicuous" filibusteros, que, para mal de los españoles, entró al Mar del Sur, en donde actuó como organizador y Capitán de diversas empresas piráticas. De su diario no hemos podido consultar otra versión que la que aparece en el tomo $\mathrm{V}$ de la traducción francesa de los viajes de Dampier, publicada en Amsterdam, en 1712. Como pasajes que sirven a nuesrto objeto sólo hemos encontrado una referencia a la región de Payta - "le térroir y est de marne \& stérile"80_-, y otra que nos habla de las nieblas de esta costa:

L'air est si plein de Brouillard dans ce Parage, quion ne sauroit voir la terre qu'à deux ou trois Lieuës de dis-

83.-RINGROSE, Op. Cit., p. 73.

$84,-$ Id. Id., p. 78.

85.-Id. Id., p. 114

86.-En "Voyage de Guillaume Dampier aux Terres Australes. . où l'on a joint... II Le jaurnal de l'expédition du Capitaine Sharp...,", Tomo V, Amsterdam, 1712, p. 196. 
tance. D'ailleurs il n'y pleut pas, mais il y tombe une si forte Rosée, que les Vallons en deviennent très fertiles; on y voit toute sorte de Fruits, \& d'aussi bon Blé qu'en Angleterre outre qu'on y recueille quantité de $\operatorname{Vin}^{8 T}$.

Se trata de una narración que, al parecer, no se propone ser sino tal, es decir una crónica de hechos, con apenas ocasionales observaciones sobre la costa, el clima, el tiempo.

\section{LIONEL WAFER}

Lionel Wafer (1660-1705), cirujano, tomó parte en muchas empresas de piratería en el Mor del Sur, en la década de 1680-90. Es particularmente célebre la relacción que publicó en Londres, en 1699, con el título de "A New Voyage and Description of the Isthmus of America... with remarkable Ocurrences in the South Sea, and elsewhere". Como el mismo to indica, trata sobre todo de sus aventuras en Panamá, y de las observaciones que realizó sobre la vida de los indios, entre los cuales vivió un cierto thempo a consecuencia de un accidente que le privó de una pierna. En la misma edición incluye un llamado al Gobierno inglés en favor del establecimientos de una base o colonia en el istmo, en razón de su importancia estratégica y de las grandes repercusiones que ello tendría en el comercio con. las Indias Zotientales. Es el aspecto etnográfico jel más imperlantel de la obra do, Wafer. Sus observaciones revelan una particular agudeza para los detalles, una apreciable objetividad dentro de sus circunstancias personales y de época, y una cierta sensibilidad frente a la peculiaridad, unidad y originalidad de las instituciones y hábitos de grupos culturales completamente diferentes al suyo. Pero no son estas observaciones etnográficas las que ahora nos interesan, sino las que realizó en nuestras costas durante los recorridos płráticos en que tomó parte en este Mar del Sur, junto con Sharp, Cowley, Cooke, Dampier, sobre todo en el año de 1686.

La visión de las costas peruana $y$ chilena le mueve a esta descripción, hecha de negaciones yuxtapuestas, como si la yerma extensión de los desiertos le exigiera esa forma descriptiva, y como si su monotonía y uniformidad se proyectasen en la reiteración de lars mismas:

87.-Id. Id, p. 196. 
At Copyapo the Coast is barren and desolate, and so on each side all along both Chili and Peru; noihing is to be seen but bare Sands, and naked Rocks, unless in a Valley now and then; no Trees, Herbs, or other green Thing. Nor did we see any sort of Fowl, nor Beast, or other living Creature. No people, nor sign of any; unless here and there a poor Town or Village, at as sorry a Port, with scarce Water enough, at most of them, to admit a Cook-boat, unless at a Flood; else, little or no Water, nor any Thing for Accomodation or use $^{\text {s8 }}$.

En esta visión lejana, construída con esas negaciones que suman objetiva y racionalmente las características de estos idénticos paisajes de litoral $-\mathrm{y}$ que sugieren, sobria y casi desnudadamente, su silencio y soledad-a las aldeas, puertos y caletas aparecen como absorbidos por el desierto, disminuídos por su inmensidad y desolación. Vistos más de cerca, Y no ya desde el mar, estos mispuertecitos y aldeas le ofrecen ofro aspecto, y los valles en los que están situados aparecen por contraste, más coloreados en su fertilıdad y abundancia, más claros y acogedores. Por ejemplo Ilo:

We went hence a little further to Lee-ward, end water'd at the River Ylo, where we got Oil-Olive, Figs, and Sugar, with several Eruits; all which grow there very plentiful. There is an Oll work, and dwo of three Sugar-works. There are extraordinary good Oranges, of the China sort. "Tis the finest Valley I have seen on all the Coast of Peru; very fertile and well furnish'd with a multitude of Vegetables, tho' it has no Moisture but that of the litle River, (which they carry winding up and down among their Grounds in Artificial Channols) and the great Dew which falls every Nigth. The Valley is the pleasanter, and so are all those of Peru and Chill, for the dismal barren Mountains that lie ali aboul, and serve as Foil to them. They are mostly sandy or flack Rocks, like Cinders or Iron Stones, for colour ${ }^{80}$.

Su descripción de la llama es una de las más curiosas que nos hayan dejado los viajeros europeos que vinieron al Perú en aquellos tiempos, tanto por su minuciosidad y detenimiento, cuan-

88-Lionel WAFER: "A New Voyage and Description of the Isthumus of America", Oxford, Hakluyt Society, 1934, pp. 120-121.

89.-Id, Id., pp. 121-122. 
to por las cuidadosas comparaciones que establece con animales del Viejo Mundo. Recuerdo bastante aquélla que leímos en el diario de la expedición de Drake, que sin duda leyó Waler, aunque es más extensa. Nos cuenta, pues:

They have here also [los indios de La Mocha] several Horses; but that which is most worthy of Note, is a sort of Sheep they have, which the Inhabitants call Carnera de Terra ${ }^{00}$.

Como Cieza de León, como Frézier, también es él sensible a la majestad y gracia de la marcha de este animal:

This Creature is about four Foot and an half High at the Back, and a very stately Beast. These Sheepe are so Tame. that we frequently used to bridel one of them, upon whose Back two of the lustiest Men would ride at once round the Island, to drive the rest to the Fold. His ordinary Pace is eithed an Amble or a good Hand-gallop; nor does he care for going any other Pace, during the time the Rfder is upon his Back ${ }^{01}$.

Parle por parte, con mucha curiosidad, lo compara luego con otras especies que le son familiares y más conocidas. Y más adelante concluye:

'Tis en innocern and verne serviceable Beast, fit for any Daudgery ${ }^{9 *}$.

Con cierta maravillada y evidente credulidad acepta y consigna las fantasiosas informaciones que habían recogido de unos españoles, las cuales atribuían extraordinarias cualidades a este auquénido:

"The Spaniards told us that these Crectures are extraordinarily serviceable to thern at the Mines of Potost.... in bringing the Silver from thence to the cities that lia toward the Sea; between which Cities and the Mines are such cragged Ways and dangerous Precipices, that it were

90.-Id. Id., p. 117 .

91.-Id. Id., p. 117.

92.-Id, Id., p. 118. 
almost impossible for any Man, or any other Beast to carry it. But these Sheepe being laden, and led to the Precipices, their Master leaves them there to themselves for above sixteen leagues; and never meets them, till he hunself has also fetch'd Compass about 57 Leagues round. This their sureness of foot consists solely in their aforesaid Claws, by which they hold themselves so fast upon the least Footing, that they can go where no other Beast can. The Spaniards also inform'd us, that at a City they named, which has no other no Water within a League of it, these Beasts, being bred up to it, were wont to be laden with two Jars, like Panniers, upon their Backs, and away they would go. without Guide or Driver; and when they came to the River, would lie down, and rowle themselves in the water until both the Jars were full; and then, of their own accord, would return home with their water ${ }^{93}$.

Nos cuenta también que hallaron en los órganos digestivos de estos animales muchas piedras de Bezoar, que por entonces tenían fama de poseer extraordinarias propiedades terapéulicas:

Ot these we killed forly-three; out of the Maw of one of which I took thirteen Bezoar-stones, of which some were ragged, and of several Forms; some long, resembling Coral; some round, and some oval; but all Green when taken out of the Mow. Yet by long keeping they turn'd of an Ash-colour, and I have some of them now by $\mathrm{me}^{\mathrm{id}}$.

Aunque nos asegura que no ha de relatarnos todo su "coasting along this shore with Captain Davis", dice que hay todavia "two Particulars more I must not omit". Nosotros hubiéramos deseado que se hubiese extendido miás largamente sobre el primero de $\theta$ llos, por su evidente interés e importancia, pero él no lo estimó conveniente, por lo visto, $y$ se detuvo más despaciosamente, por ejemplo, en la descripclón de la llama. Sin maravillarse, aunque consciente de que éste era una noticia curiosa que no debía omitir. nos cuenta que cuando desembarcaron en Huarmey, en busea do agua:

we marched aboul four Miles a Sandy Bay, all which we found covered with the bodies of Men, Women and Chil-

93.-Id. Id., p. 119.

94.-Id. Id., p. 118 . 
dren; which lary so thick, that a Men might, if he would, have walkend half a Mile, and never trod a Step off a dead human Body. These Bodies, to appecrance, seem'd as if they had not been above a Week dead; but if you handled them, they prov'd as dry and light as a Spunge or piece of Cock $^{\text {sis }}$.

En las Inmediaciones de este lugar encontraron $\alpha$ un viejo "Spanish-Indian", pescador, el cual, respondiendo a sus preguntas, formuladas en español, sobre aquel sitio y la causa de que aquellos cuerpos estuvieran allí, les respondió de esta manera:

That in his Father's Time the Soil there, which now yielded nothing, was green, well-cultivated and fruitful: that the City of Wormis [Huarmey] had been well inhabited with Indians: and that they were so numerous, that they could have handed a Fish, from Hand to Hand, 20 Leagues from the Sea, until it had come to the Kings or Ynca's Hand. That the Hiver [de Huaymey] was very deep, and the Current strong: and that the reason of those dead Bodies was, that when the Spaniards came, and block'd up and lay'd Siego to the Oity, the Indions rather than lie at the Spaniards Mercy, dug Holes in the Sand, and buried themselves alive. The Men as they now lie, have with them their broken Bows, and the Women their Spinningwheels, and Distaffs with Cotton yarneupon them ${ }^{p 6}$.

Wafer consigna este "Jestimonib escuetanente, sin decir nada sobre su veracidad o verosimilitud, sin manifestar admiración o sorpresc. $Y$ luego nos cuenta:

Of these dead Bodies I brought on board a Boy of about 9 or 10 Years of Age, with an intent to bring him home for England, but was frustrated of my purpose by the Sailors; who having a foolish Conceit, that the Compass would not traverse aright, so long as any dead Body was on board, threw him overboard, to my great Vexation ${ }^{97}$.

Como se ve, aquí aparece sobre todo el hombre curioso, el cirujano, y su justificado pesar le esconde la clerta comicidad del epi-

95.-Id. Id., p. 122 .

96.-Id. Id., p. 123.

97.- Id. Id., p. 123. 
sodio. Casi un siglo más tarde, en sus paseos por nuestras playas, el Padre Feulleée hallaría otros cuerpos en estado semejante.

El segundo "parifcular" cque nuestro autor no quiere omitir, narra un encuentro no menos sorprendente y curfoso, pero de urvalor más que nada anecdótico:

Here [en Santa] I went ashore and so up to the Town, which was three Miles or thereabouts from the Sea. In our way to the Town we cross'd a small Hill; and in a Valley between the Hill and the Town we saw three small Ships of about 60 or 100 Tuns apiece, log'd there, and very ruinous. It caused in us great Admiration, and we wore puzzled to think how those Ships could come there ${ }^{\text {gs }}$.

Fue otra vez un indio de los alrededores que les explicó el misterio: hacía unos nueve años, más o menos, un fuerte terremoto hizo retroceder las aguas de la bahía hasta más allá del horizonte, pero a las veinticuatro horas tornaron otra vez, con extraordinaria violencia,

tumbling and rowling with such Violence, that it carrled these Ships over the Town, which then stood on the Hill which we came over, and lodged them there; and that it destroyed the Country for a considerable way along the Coast ${ }^{\text {pa? }}$.

\section{"Jorge Puccinelli Converso"}

Este informe les tue confirmado por el párroco y varios habitantes del lugar. Y también esta vez Wafer consigna el hecho sin ningún comentario.

\section{EDWARD COOKE}

Edward Cooke fue "first liutenant of the Duchess" en la expedición de Rogers, y la relación que sobre ella escribió, "A Voyage to the South Sea and round the World, perform'd in the years 1798 , 1709,1710 , and $1711 \ldots$. , apareció en un solo volumen en 1712 . Maggs (citado por Cox) advierte que hubo, aparentemente, una gran competencia entre los edifores de Rogers y de Cooke para

98,-Id. Id., p. 123.

99-- Id. Id., p. 124. 
lanzar sus respectivas relaciones al mercado. El libro de Cooke apcreció primero, pero con su parte final redactada rápida y aun precipitadamente. Pronto fue reimpreso el mismo año, en una edición cumentada, en dos volúnenes, que es la que hemos consultado. Pero sl éste -el relato de Cooke salió a luz ontes que el de Woodes Rogers, le es inferior, en cambio, desde muchos puntos de vista. Es un diario escrito en lenguaje seco, pobre, privado de Imaginación, que no tiene la fluidez narrativa, clara y agradable, ni la facilidad para caracterizar personajes y sugerir sifuaciones, que se atribuyen el diario de su superior. Sus cartas nóuticas a hidrográficas no tienen tampaco la exactitud que se concede a las de Rogers.

En el capítulo XI del Vol. I, entre otras informaciones relativas a las corrientes y a la navegación, hay una fugaz apreciación del paisaje de la isla de Lobos, expresada en una serie de negacto. nes. En medio de la esperezcr y obscuridad de su lenguaje nos revela una impresión fuerte $y$ yiva, $y$, aunque elementar $y$ fugitlva, se destaca dentro del estilo general del diarlo, gris a inculto:

It lles in 6 Deg. 5 Min. Latitude South, about 16 Leagues from the Continent, is barren, and looks like some Par! of Scilly; but na so good, and affords neither Wood nor Water, nor any green Thing, yery Rocky, with several veins of Slate ${ }^{100}$.

Este pasoje nos récuerda a Warer, plies entamblen describe mediante negaciones nuestro paiscije de la costa ("no Trees, Herbs or other green Thing"). An continuación del mismo, Cooke nos describe, de una manera irremediablemente obietiva, los pingüinos y los pelícanos de aquel lugar.

El capítulo XIII del primer volumen contlene una descripción de Guaraquil, sobre la base de lo que su autor vio personalmente $\mathrm{y}$ de lo que le informó un inglés que había vivido cierlo tiempo en esa ciudad. La escasa e impersonal adjeltveción que usa en ella, apenas si adquiere una leve viveza cuando habla de los templos y las casas. Las iglesias "were all decently adorn'd with altars \& carv'd work, Pictures..." 101. Algunas de las casa esta-

100.-Edward COOKE: "A Voyage to the South Sea and round the World", Londires, 1712, p. 127.

101.-Id. Id., p. 149 . 
ban también "decently furnish'd". Con cierta sorpresa e ironía conota que:

The Inhabitants had some Calashes; but I know not of what use they could be, unless to carry them a stone's Throw to Church, especially in Winter, all cbout being so souland boggy 202 .

La maravilla que le cáusa el enorme grandor de los sapos de la región le mueve a una graciosa comparación:

This Morass Ground was full of the largest Toads I ever saw, some of them as big as an English Two Penny Locaf ${ }^{103}$

Del paisaje de Guayaquil, propiamente, no nos dice nada en absoluto, $\mathrm{y}$ en cambio nos da ciertas distancias $\mathrm{y}$ vagas indicaciones sobre su situación favorable para el comercio.

Los capitulos XV y XVI de este primer tomo tratan sobre "The just distances between all the Ports, Bays, and Creeks on the Coast of Peru, as also the Islands, etc.", descripción redactada según un "Spanish Manuscrit Coasting Pilot". No nos ofrece interés por su carácter casi exclusivamente técnico.

Los capítulos XVII Y XVIH iraen una síntesis descriptiva del $\mathrm{Pe}$ rú, relativamente bien realizada, que glosa, con algún sentido de selección, los téstimonios delos cronistas españoles que dice utilizar como fuentes: Herrera, Garcilaso y Cieza. Toma de ellos la descripción del clima, animales, plantas, religión de los antiguos peruanos, sus costumbres. etc. Dice también haber "collected all that is remarkable and authentic in all other Spanish Writers".

\section{- WOODES ROGERS}

En Agosto de 1708 partió de InIglaterra una expedición de dos barcos de guerra privados, organizada por varios comerciantes de Bristol, con el objeto de atacar el litoral de las colonias españolas del Mar del Sur, y apresar los buques que en él se encon-

102-Id. Id, p. 149.

109.-Id. Id., p. 149. 
trasen. Comandante general de la misma fue nombrado Woodes Rogers, y Piloto William Dampier. Esta expedición no solo fue un éxito desde el punto de vista "económico", sino también en lo que respecta a organización y disciplina ${ }^{104}$, pues hubo buen orden no obstante la curiosa variedad de orígenes de los tripulantes, muchos de los cuales eran "tailors, tinkers, pedlars, fiddlers, and haymakers"105 - . Y la constante insubordinación de algunos oficiales. Recogió en la isla de Juan Fernández - a la cual llegaron por un azar feliz, pues su posición no era todavía entonces exactamente conocida- al después célebre Alexander Selkirk, principal fígura en la génesis del "Robinson Crusoe". Durante varios meses piratearon en las costas del Perú, capturando muchos buques pequeños $y$ un gran velero, y poniendo a saco y cobrando rescate luego por el puerto de Guayaquil. Continuaron después hacia el Norte, hasta la altura de California, y, atravesando el Pacífico, tocaron en las Filipinas, en la ruta a Europa por el Cabo do Buena Esperanza. Llegaron a Inglaterra el $1^{\circ}$ de Octubre de 1711. El año siguiente, precedido por el de Edward Cooke, que también había participado en la empresa, se publicó el diario de Rogers, en una edición que es hoy muy rara y que no nos ha sido accesible. Tampoco nos ha sido accesible ninguna otra edición inglesa, y nos hemos tenido que resignar a la consulta de una traducción francesa aparecida en Amsterdam, en 1716, con las obvias limitaciones $y$ reservas del caso. (CElatitulo inglés es: A Cruising Voyage round the World; first to the South Seas; thence to the East Indies, and homeward by the Cape of Good Hope...". Londres, 1712). Esa circunstancia nos es más sensible por cuanto este diario es comúnmente celebrado por la claridad y soltura de su relato, por la vivacidad de su estilo, por su sentido del humor, cualldades éstas de que nos da desmayada idea la traducción que usamos -pero así, es posible todavía entrever algo de esas virtudes del original. Contiene esta relación curiosas noticias sobre las colonias españolas, recogidas de los testimonios de los prisioneros o de los documentos capturados en las naves que apresaron.

La introducción de Rogers a su diario comprende interesantes declaraciones ecerca del objeto de estas relaciones y diarios de navegación, del estilo más natural y conveniente en que de-

104.- Ver el artículo correspondiente en el "Dict. Of. Nat. Biog." 105.-Citado por Maggs en el "Dict. of Nat. Biog.". 
ben estar escritos, de la objetividad y sencillez que deben guardar, etc., tal como hemos visto en nuestro Estudio Preliminar, en lo referente al estilo.

Dentro de esa sujeción a la objetividad, llana y precisa, que Rogers aconseja, tenemos esta breve noticia de la Cordillera de los Andes:

Le 2 [Marzo de 1709] Nous étions a 12 ou 14 Lieües de la terre, où nous vîmes une chaîne de hautes Montagnes, qu'on apelle Cordilleras, qui parcissent, tout le long de cette route, avec le sommet couvert de neige, \& dont quelques-unes sont du moins coussl hautes que le Ple de Tenerife ${ }^{100}$.

Semejantes en estilo y objetividad -objetividad ésta precisa e inteligente, y no producto de una falta de imaginación y rudeza de espíritu, cuando no también de la incultura, como la objetividad que hallamos en las relaciones de otros piratas-, son sus descripciones de la isla de Lobos y de Guayaquil. La idea de las riquezas del Perú y la de la codicia y crueldad de los españoles apare? cen asociadas en estas líneas:

Je ne cétaillerai pas un nombre infini d'autres moïens injustes quils [los oficiales, conregidores españoles] ont pour

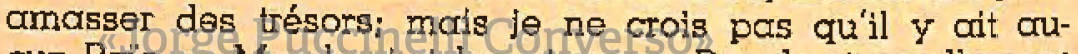
cun Pois ca Monde si richo, ni oucun Peuple si cruellement opprimé que celut-cl107.

Y nos remite luego al testimonio de los mismos españoles, en confirmación de lo que ha dicho:

Les espagnols disent eux-mêmes, qu'un Viceroi, après avoir emploié tout ce qu'tl aroit en Espagne pour l'acquisltion de sa Dignité, \& s'être rendu por là plus pauvre que Job, vient dans ce Pays comme un Lion affamé qul dévore tout de qu'il trouve, \& que les Officiers établis dans les Provinces, oú il y en a dix fois qu'll ne faudroit, lut servent de Jackals pour lancer la Prole, \& s'en repaitre avec lui ${ }^{109}$.

106.-Woodes ROGERS, Op. Cit., p. 214.

107.-Id. Id, p. 288-287.

108.-Id. Id., p. 287. 
Considera luego que con mejor goblerno y mejores leyes, y habiendo un pueblo industrioso, el oro y la plata perderían en esta tierra su valor de rareza:

On peut ajouter à $\mathrm{ce}$ grief le polds insuportable d'une infinité d'ecclesiastiques, abandonnez ou luxe, a la mollesse \& à la superstition, plus que doms aucun Païs de l'Europe: en sorte que, s'il avoit tci un Peuple industrieux, gouverné par de bonnes Loix, il est à craindre que l'Or \& l'Argent ne divinssent si communs, qu'on seroit bientot obligé de recourir à quelque autre moien pour satisfaire l'avarice \& l'intemperance des Hommes ${ }^{109}$.

$Y$ como una pequeña muestra de su sentido del humor - sentido del humor y fluidez de la narración no reñidos con su preocupaclón fundamental de objetividad y lloneza-- citamos este episodto (no acontecido en el Perú)), del cual fue protagonista un religtoso español que tomaron prisionero en un barco, de los tantos que capturaron a lo largo de sus recorridos:

Nous débarquames ici [en la costa de Tecames] notre jeune Padre, qui nous demanda la plus jolie Négresse qu'il y out à bord de la Prise. Il l'obtint \& s'en alla plein d'envie de se trouver seul avec elle $e^{110}$.

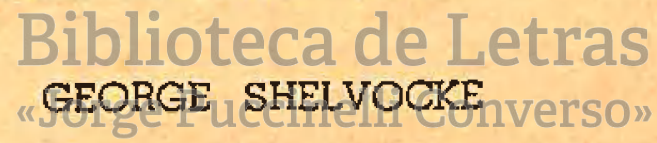

La expedición inglesc de Clipperton salió de Inglaterra en Noviembre de 1718. Pocos días después, una fuerte tempestad dispersó la pequeña escuadra en que consistía, de manera que se dividió en dos grupos, uno, el de Clipperton, y otro que qued6 al mando de George Shelvocke. Este continuó navegando hasta el Estrecho de Magallanes, y siguíó luego a Chiloé, Concepción. Arica, la isla de Lobos. Saquearon Paita, y nuevamente regresaron hacia el Sur, a la isla de Juan Fernández; permanecieron aquí un corto tiempo, y tornando luego al Norte, tomaron por segunda vez Palta, (fines de 1720), y continuando hasta la altura de Méjico, se encontraron con la nave de Clipperton, y volvieron a Europa por el Cabo de Buena Esperanza.

109.-Id. Id., p. 287.

110.-Id. Id., p. 355. 
El mayor "mérito" de Shelvocke, de su diario, está quizás en la circunstancia de haber servido uno de sus episodios -acaecido en aguas de Africa- de motivo de inspiración de la balada del Viejo Marinero (el albatros) de Coleridge.

El diario de este filibustero no nos ofrece testimonios más numerosos que los otros que nos han dejado sus camaradas de oftcio; pero, con todo, tiene cierta viveza en el relato, y una adjetivación más frecuente y más personal. De Arica nos cuenta (Febrero de 1720) que se halla ruinosa, casi privada de las riquezas que en otro tiempo la habian hecho famosa, y que "appears to be no other than a heap of ruins, except the church of St. Mark, and 2 or 3 more, which look tolerably well". Y luego, no acostumbrado todavía a las techumbres curiosas que permite el clima de este litoral, reacciona de la misma manera como podría hacerlo hoy un honrado turista americano o inglés:

That which helps to make it look the more disconsolate is that the houses below are cover'd only with mats ${ }^{111}$.

Del guano que se cargaba en Arica y también del que había en la isla de Iquique, nos dice con toda sinceridad que es "very offensive". Del paisaje costeño adyacente dice:

for the country of itself is barren, being, as it were made up of continued chatns of vast Sandy mountains, perpetually parch $d$ by the heat of the sun, so that here is not the least verdure to be seen; except in the vale of Arica ${ }^{112}$.

Y a propósito del guano de la isla de Iquique:

'tis not in this place only that one sees large quantities of it; but also all along the coast of Peru, there are lofty preciplces, and large rocks near the sea, cased over with it, which at a distance make them appear like chalk-cliffs ${ }^{119}$.

Su descripción de la isla de Lobos es más vívida, y hasta literaria:

111.-George SHELVOCKE: "A Voyage round the World by the Way of the Great South Sea", Londres, 1723, p. 170.

112.-Id. Id., p. 170.

113.-Id. Id., p. 270. 
These Islands situated in about 7 deg. South latitude, within sight of the Continent, look, when beheld from the sea, like continued rocks; there is not the least verdure to be seen on them, and when you are ashore, the ground is burnt to that degree, that the surface of it appears like a cinder ${ }^{114}$.

Las islas abundan en pájaros de diversas especies:

Here are also plenty of Guanoes and Carrion-crows, which, with their red gills, as they sit perching among the rocks, bear the exact resemblance of a Turkey ${ }^{115}$.

Cuenta también, con un estremecimiento horrorizado que se comunica al lector:

Here is a spacious rocky cave, the retreat of the Seals, whose continual howlings ecchoing all around the obscure grotto, render it a place of as much horror as the imagination of man can feign ${ }^{11 \%}$.

Nos figuramos bien, y lo compartimos en cierta manera, el horror que la imaginación supersticiosa del pirata debió experimentar en aquel sitio, en donde se reunían la obscuridad subterránea, el misterio del mar, y los aullidos de esos animales que multiplicaba la resonancia de la caverna. Ningún otro corsario e pirata nos ha participado un sentimiento semejante.

Su descripción de Payta es notablemente huérfana de sabor, y no anota otras observaciones interesantes que las relativas a los altares de sus iglesias:

the churches are well adorned within with several handsome altars, indifferently painted and carv'd, but richly gilt, and, in all respects, beyond any thing one would expect from a first view of the place, which is low, and ill built with unburnt brick, the roofs of some being cover'd with mats, \&c. and other miserably thatch ${ }^{1117}$.

Alude también a los magníficos trabajos de ebanistería que ador-

114.-Id. Id., p. 183.

115.-Id. Id., p. 184.

116. -Id. Id., p. 184

117.-Id. Id., p. 290. 
naban la casa del Gobernador, y a la raza mezclada de los habitantes. Dol lugar on que la ciudad está situada nos dice:

the whole country, whether hill or valley, about it, appears as if parch'd, and never moistened by the descent of rain, so that there is not any thing green to be seen round it, the land about being productive of no necessary, not so much as water, which is brought in Jars upon barkloks from Collan (which I have before mention'd) as well as almost every thing else; so that there is nothing to recornmend this desart but the commodiousness of the harbour ${ }^{118}$.

Advirtamos que en tres oportunidades remite al lector a la obra de Frézier, "Rélation du Voyage de la mer du Sud coux côtes du Chily et du Pérou", que parece conocer bastante bien.

\section{WILLIAM BETAGH}

En 1728 se publico en Londres "A Voyage round the World, being an account of a remarkable enterprize, begun in the year 1719, chiefly to cruize on the Spaniards in the Great South Ocean", de William Betagh, "Captain of Marines" en la expedición de Shelvocke, cinco cños después de la publicación del diario de éste último. Su autor declarácexpresamente quieesu propósito principal es "undecelve mankind in the spurius account of a Voyage round the world published by Captain George Shelvocke, which account is not only injurious to me, but is enterely the most absurd and false narrative that was ever deliver'd to the publick". Efectivamente. Shelvocke no habla de él, en su diario, en términos particularmente calurosos, pues, entre otras cosas, lo acusa de haber exigido, sin mucha cortesía ni conveniencia, el cumento de su ración alimenticia y el derecho a sentarse en la misma mesa que él, $y$, sobre todo $y$ más particularmente, de profesar las mismas creenctas religiosas que los espoñoles, y de haberlos revelado el propósito de la expedición. No es muy claro quién tuviese la razón, y ros abstenemos de concedérsela a uno u otro, no sólo por lo obscuro del diferendo que los opone, sino también por la simpatía que nos inspiran la viveza y desenvoltura del estilo y el "esprit" con que Betagh ha escrito su diario. Y nos felicitamos por la

118.-Id. Id., p. 291. 
circunstancia que separó el pequeño buque en que iba Belagh del de Shelvocke, en las aguas vecincs a Payla, y por su posterior cáída en manos de los españoles, que lo llevaron, a él y a sus hombres, primero a Piura y después a Limc, proporcionándola ocasión de efectuar las observaciones de que nos da cuenta. Gentilmente, él mismo nos informa sobre el objeto de ellas:

Beside our sea journal, I have collected the observations I made while in the kingdoms of Chili and Peru, concerning the Spanish dominions in America. The trade, customs, luxury, and gallontry of the Creolions. To which I have added an croount of their gold and silver mines, their manner of separating the mineral from are, and many other things; all which together, I need not doubt, will prove an agreably history of this Voyage ${ }^{110}$.

Ninguna relación de corsario o fillbustero trata de tan curtosos y tales temas, cunque es verdad, también, que pocos tuvieron la oportunidad de realizar las observaciones que tan sosegadamente efectuó nuestro autor. Por lo que sabemos de estos diarios, creemos que es improbable que lo hubieran hecho con ton excelente sentldo del humor y facilidad de longuaje como Betagh. Sólo, es de suponer, la relación que pudo haber escrito Richard Howkins sobre su estancia en el Perú, habría tenido una fluidez narrativa semejcnte, y acaso un mayot valor testimonial ednformativo. Pero Hawkins no la escribió, P si don hizo. ella sep perdió. Ninguno, tampoco, tiene la curiosidad en cierto modo periodística que anjma a Betagh, esa objetiviciad suya que no es la impersonal, científicar, forzosamente concentrada objettvidad de Dampier. Ninguno tiene su simpatía y cordialidad por lo observado, que no excluyen la critica, y a las cue consideramos exentas de toda sospecha. Es notable el cierto refinamiento que hay en su afición a lat vida muelie, y nos admira que sea capaz - cosa extraordinaric en esta clase de literatura- de poder citcr a Shakespeare.

Desembarcados en Poyta, nuestro autor y sus compañeros fueron confiados a un guía indígena para que los condujera a Piura. En razón del excesivo calor diurno el viaje solía hacerse por entonces al atardecer $\mathrm{Y}$ durante la noche. El guía, no sabemos si con cierta ironía, o en el entendimiento de la insólita cali-

I19.-William BETAGH, Op. Cit., pp. 2 y 3. 
dad del prisionero, le ofreció su mejor mula, sobre la cual nuestro filibustero se echó a caminar sobre la abierta llanura del desierto, teniendo a una mano la Cordillera, y a ia otra el Océano. como él mismo nos lo puntualuiza. Nos dice, pues, que mientras hubo luz de día:

I observed the country one open piain, with Indian plantations regularly enough cantond out on each side of Lis. ${ }^{120}$.

Y líneas mós adelanto leemos:

If this land was well waterd, as the soil is pleasant and fertile, it might be as tine a country as any: but travellers are here obliged to carry water for their mules as well as themselves ${ }^{191}$.

Al anochecer, nos refiere, no poco desconcierto le produjo el toparse, a menudo, con dunas y montoñas de arend, y que la mula se esforzaba por hacerle sol tar las riendas de la mano, como que estaba acostumbrada a caminar como más le placía, "not caring to follow company". Tuvo dcasión de advertir la frecuencia con que esas colinas de arena cambiaban de lugar, fenómeno que atribuye a los tuertes remolinos de aire reflejados ("reverberated") por las montañas. Y. tarde la nache, recuerda, cuando estaban ya por domirse, acostados en la arena, sentía a las sedientas mulas ir a escarbar en el suelo en busca de unarciertas taíz no muy diferente de la planta que llama "parsnip" (chirivia), que guarda en su interior una gran cantidad de zumo fresco. Y si tal vez, de puro impacientes y agotadas, no acertaban a desenterrarla, se estaban quietas junto al sitio en donde presentían su existencia, hasta que el arriero indio iba y les ponía al descubierto lo que buscaban ${ }^{122}$.

En Piura, "a regular handsome town", a la cual ilegaron muy de mañana, fueron conducidos a la casa de "a good Spanish gentleman". llamado don Jerónimo Baldivieso. En un cuarto de hora. nos cuenta, "the towns people flockd in to see the rary show" ${ }^{\prime \prime 23}$, lo cual más bien les causó gracia. Fueron tratados con una grande y no esperada cortesía:

120.-Id. Id., p. 245.

121.-Id. Id., p. 245.

122.-Id. Id., p. 291.

123.-Id. Id., p. 246. 
and instead of being used like prisoners at discreilon, wo were entertaind with respect and clvility, which we were not sure to meet with ${ }^{124}$.

Shelvocke dirá al respecto que usaron con Betagh de esa cortesía porque era "of their religion, and of a nation which the Spaniards are very fond of - con lo cual, acaso, quería dar $\&$ entender que era irlandés. Betagh conservó hacia ese caballero un reconocimiento semejante al que Hawkins guardó a don Beltrán de Castro. Pero, $\alpha$ pesar de ese agradecimiento, que creemos muy sincero, nos parece advertir cierta malicia cuando nos cuenta que:

He had five daughters, upon the sight of which and their condid way of recelving us, we hoped our time would siide easily away, and our captivity prove agreeable ${ }^{12 \overline{5}}$.

Y para completar tan magnifica acogida, he aquí como al obligado refrigerio sucedió otra no menos curiosa manifestación de hospitalidad:

Soon as we had refreshd ourselves, according to the custom of the place, with chocolate, biskets and water, we were diverted with sound of a Weich harp in some inner apartment: the artist had good command of $\mathrm{tt}$; for I heard parts of several irrous haliom cas well as English compositions, and upon inquiry, was informd that all the Spaniards doughters hod learnt music, and sung or ployd upon some instrument or other ${ }^{128}$.

Luego, más tarde, descubrió que lo que entonces les pareció sorprendente, estaba en recilidad muy difundido, pues el Virrey Príncipe de San Bueno, que era italiano, había traído consigo muchos músicus de su misma nacionalidad, los cuales habían divulgado la música de su país por todo el reino, $y$ era tan buena aquí como en la vieja España. De aquella monera, pues,

by means of music and an inoffensive carricge, we lived in good harmony with those who had a right to treat us as ennemies ${ }^{127}$.

124.-Id. Id, p. 246.

125.-Id. Id., p. 247.

126.-Id. Id, p 247.

127.-Id. Id., p. 248. 
Realmente, no podemos dejar de considerar ediflcante el ver cómo la rudeza y barbarle de estos filibusteros parecía haberse tornado en inocente $y$ espiritual sensibilidad por obra de unas niñas que sabían tañer hermosamente el harpa. Más adelante nuestro autor nos cuenta cómo estos pasatiempos se alternaban con las visitas de los vecinos, que menudeaban durante todo el día:

It was a practice here every day for the neighbours to come and view us; at which I was well enough diverted ${ }^{128}$.

Desdichadamente, tan distraída y placentera existencia tuvo fin, pues fueron llevados - los piratas- nuevamente a Payta, $\mathrm{y}$ conducido en un buque de guerra a Lima, en un despacioso viaje que duró nada menos que cinco semanas. En esta cludad. la recepción fue un poco menos calurosa que en Payta, pues los echaron on prisión y sometieron a juicio, pero la buena suerte no abandonó a Beiagh, ya que luego de algunos sustos, fue liberado, a lo cual contribuyó mucho la intercesión de un mercader originario de Saint Malo, Monsleur Fitzgerald, por entonces valido del virrey. Libre, pues, supo que sus compañeros de cautiverio se habían convertido al catolicismo, y que se habían dispersado devotamente por los conventos de la ciudad. Con su natural donayre de estilo y buen humor, nos naria como se topós un día con uno de ellos:

\section{"Jorge Puccinelli Converso"}

The first that I saw has got his new catechise in one hand, and a pair of large beeds dangling in the other. I smiled, and askd the fellow how he liked it : he sald very well, for having his religion to chuse, he thought this better than none, since it brought him good meat and drink, and a quiet life ${ }^{128}$.

Parece que los nuevos conversos tomaron su nueva fe con entusiasmo algo excesivo, pues, en cuanto les fue posible, se reunleron en la tienda de un paisano suyo, oportuna y simbólicamente llamado John Bell (el cual, por más señas, estaba casado con una negra, a la cual había emancipado por no se qué parttcula-

128.-Id. Id, p. 248 .

129. -Id, Id., p. 253-254 
res servicios, según apunta el mismo Betagh), para celebrar dignamente su reciente conversión:

The design of this meeting was to confirm their new baptism with a bowl of punch : the consequence of which was, they all got drunk and quareld; and forgetting they were true catholics, mistook an image of some good saint that stood in a corner for one of their own company, knockd him down, and demolishd him ${ }^{130}$.

Como es de suponer, tan poco ortodoxa conducta llegó prestamente a oídos de la Santa Inquisición, la cual, con su habitual rapidez, los puso nuevamente en prislón. Pero alli en donde un nativo de esta terra, que hubiese cometido tal delito, hubiera dejado la hacienda y la vida, nuestros piratas hicieron valer su condición de "novicios" o "neófitos", y fueron cristianamente perdonados. Tiempo después, $\sin$ embargo, proyectaron apoderarse de un buque en el Callao y fugar, pero su plan fue descubierto. Pero otra vez, también, salieron del apuro con apenas leves castigos. Estas dos historias mueven a Betagh a expresar, con una precipitación que no sabríamos reprocharle, la siguiente declaración:

but both these stories are an argument, that neither the church nor state are so rigorous in Peru, as the Romish dominions in Europe ${ }^{181}$

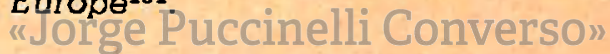

Su descripción de Lima, breve - más breve, por ejemplo, que la de Frézier-, es asaz vívida, y en ella se suceden el donayre, la malicia, la gravedad o la ironía, según los aspectos a los cuales se refiere. Sin duda a causa de haber nacido y vivido en cludades de Europa, cuyo plano era todavía bastante medieval, encuentra cómoda y espaciosa la disposición urbanística de Lima:

Lima is the metropolis of Peru and the seat of an archbisshop. "Tis a regular built city, the sireets all strait and spacious : so that you go thro' it almost any way without turning a corner [cosa que no se podía decir, por ejemplo, del Londres de esa época]. It is composed of little squares like St. Jago the capital of Chill, wich is copyd from this. It

130.-Id. Id., p. 254-255.

131.-Id. Id, p. 257. 
stands in an open vale, having only a gentle stream to water it [quizás en aquel tiempo el Rímac merecía este adjetivo]; and which divides it as the Thames does London from Southwark, allowing for the great disproportion ${ }^{132}$.

Enumera las variedades raciales que se encuentran en la ciudad, tan complicadas, que mucha gente hacía ciencia de conocerlas, y halla divertido el que se sientan extranjeras unas con respecto a otras, y tengan un cierto desprecio por las que se encuentran debajo según la jerarquía establecida de acuerdo a la mayor o menor proporción de sangre blanca. En dos oportunidades Betagh alude expresamente a las diferencias raciales, que hacian que las caras blancas, "white face", encontrasen muchas mayores posibilidades que los demás grupos étnicos (lo cual explica el caso de los desertores de norves europaas, que escogían al establecerse aquí en razón del "incouragment all white faces meet with" 133). Y dice todavía al respecto:

Indeed the Nigros and Indians do all the work; for a white face is exemption enough from all labour and care ${ }^{184}$.

Se muestra sensible a la desdichada condición de los indios, y nos cuenta los abusos y extorsiones de que eran objeto por parte de los corregidores, comerciantes, buhoneros, $y$ S cómo sobre ellos reposaba todo el trabajo sobre el cual se asentaba esa feliz existencia de Lima, que, como veremos, celebra entusiastamente. Pero no se interesa particularmente en describirnos la historia y sociedad del antiguo Perú, anteriores a la conquista española, no sabemos si debido a la falta de una oportunidad propicia, o por considerar que esto era ya suficientemente conocido en Europa, - acaso, también, porque sus inclinaciones y tipo de cultura no le movian a ello. No obstante, alude en cierto momento a esa edad feliz de los indígenas - por los que siente una verdadera y evidente compasión-, anterior a su desgraciada sujeción por España:

The want of rain in this part of the continent obliged the poor, I should say happy Indians, before the conquest,

132. -Id. Id., p. 258.

133. -Id. Id., p. 259.

134.-Id. Id., p. 278. 
to make dreins and cancis, for bringing down water from among the distant mountains: which they have done with such great labour and skill that the vallies are kindly refresht, producing grass, dorn, and variety of fruits : to which the aforesaid dews may also a little contribute ${ }^{135}$.

Esta es la única, aunque bastante expresiva referencia a una edad de oro peruana, cuya leyenda no debió desconocer.

Del gran lujo al que eran aficionados los habilantes de Lima, y que mostraban en sus vestidos y flestas, nos da varios testimonlos. Dice, pues, por ejemplo:

Of all parts of the world, the people here are most expensive in thelr habits ${ }^{136}$.

$Y$ aludiendo a una costumbre que, según tenemos entendldo, no ha desaparecido todavia de muchos hogares de Lima y de provincias, nos cuenta con manifiesta Ironia:

But the pride of both sexes appears chiefly in Maclin and Brussels lace, with which they trim their linnen in a most extravagant manner, not omitting thelr sheets and pillows ${ }^{157}$.

Advirttó también que les limeños usaban una gran cantidad de perlas y piedras preglososientsus atgrios. "though the value is hardly equal to the appearance"138, Y al describirnos aquel fastuoso recibimiento que se le tributó al Duque de lá Palata, cuando se empedró una calle con barras de plata que valían por lo menos "2500 dollars" cada una, nos dice que:

which plece of finery I can liken to nothing but the account we have of Jerusalem in the days of king Salomon ${ }^{189}$.

Nos parece curioso que compare aquella muestra de ostentación y magnificencla con la legendaria riqueza de Salomón -más bien que con la leyenda de las ríquezas y tesoros de los incas, más próxima, sin embargo, cronológica y geográflcamente.

135.-Id. Id., p. 268.

136.-Id. Id., p. 260.

137.-Id. Id., p. 261.

138.-Id. Id, p. 261.

139.-Id. Id., p. 263 . 
En cuanto al clima de Lima, pondera su templada temperatura; que no corresponde a su latitud. Este fenómeno, a su entender, se debe al aire proveniente de la vecina cordillera, y a la humedad de los vapores suspendidos sobre la llanura del litoral :

These vappours are not so coarse, low and humble as our fogs, nor separated above like our summer clouds ${ }^{140}$.

La vista de éstos, durante sus primeros días en la ciudad, le hacía esperar una pronta lluvia. Estima su existencia como una feliz circunstancia, pues los habitantes están de ese modo protegidos ("screend") del sol una mitad del día - lo mismo dirá Anson-, y en la restante el ardor del sol se ve temperado por las brisas que vienen del mar. Le reprocha a Frézier, cuyo libro conocía desde luego, el no seguir la opinión de Zárate en sus explicaciones de la sequía permanente del clima costeño.

Pero el aspecto de la vida limeña que con más placer evoca Betagh, es, sin duda, el del amor. Su estilo es entonces aún más desenvuelto, más vivo y natural, y de tal manera recrea ante el lector todo este clima novelesco, que desaparece lo que puede haber de convencional en la pintura semejante atmósfera de aventuras, galanteos, duelos y noches que parecen permanentes mascaradas. Y no se advierte tampoco ninguna pretensión de hacer literatura. Suponemos con toda buena fe que el entusiasmo que muestra en estás observaciones y evocación no es sólo documental, sino que debe ser además producto de gratas y memorables experiencias personales. No conocemos autor extranjero -o por lo menos de su nacionalidad-, que diga cosas semejantes, y tan ponderativa y celebratoriamente, como cuando comienza, por ejemplo, a tratar de ese agradable tema :

Tho' the Spaniards are not friends to the bottle, yet gallontry and intrigue are here brought to perfection, for they devote so much of their time to the service of the fair sex, that Venus seems here to keep her court. It is unmannerly not to have a mistress, and scandalous not to keep her well141.

Nadie ha celebrado como él, en su época y en su idioma, con tanta galantería, a las limeñas, en las cuales halla admirablemente

140.-Id. Id., p. 267.

141.-Id. Id., p. 270. 
proporcionados el físico hermoso, lleno de gracia en los movimientos, y el donaire y espiritualidad del ingenio. Nos dice, pues, anteponiendo estas últimas cualidades a las de la belleza corporal :

As for the women they have many accomplishments both natural and acquired; their conversation is free and sprightly, their motion graceful, their looks winning, and their words ingaging : they have all a delicale shape, not injured with stiff bodyd stays, but left to the beanty of nature; so that there's no such thing as a crooked body among them. Their eyes and teeth are particularly excellent, and their hair being generally of a dark polisht hue is finely combd, and platted or tyd behind with ribands, but never disguised with powder: for the brightness of their skin round the temples appears very well shaded thro' the hair like light thro' a landskip ${ }^{1 * 2}$.

Esta última es, en verdad, la única comparación "literaria" que hayamos encontrado en los textos que interesan a nuestro estudio y que hemos consultado. Hemos visto que, según sus observaciones, es "unmanerly" el no tener amante en Lima, y escandaloso el no mantenerla bien, no obstante lo cual, medianie una serie de convenciones, las relaciones de amor se mantienen en un confortable climá de particular discreción:

Tho' these amours are universal at Lima, yet the men are careful enough ed hide them; Connelindecent word or action is allowd in public. They have two usual times for these entertainments... ${ }^{143}$.

Además de las pláticas de la hora do la siesta y del anochecer. los hombres, después de las plegarias de la noche, salen a la calle - a "ruar", como hubieran dicho los clúsicos del Siglo de Oro- vestidos con tal artificio, que están como disfrazados:

so that it is a universal fashion to be disguised some way or other; for those who have no mistress are ashamed to be thought strictly virtuous, and must be in some mask or other to countenance the way of the world. But as all this, is night work, they have on establisht rule to prevent qua-

142.-Id. Id., p. 271.

143.-Id. Id., p. 270-271 
rels, which is never to speak or take notice of one another; whether they are going in quest of amorous game, or visiting their ladies : so that in short the forepart of the night is a masquerade all the year round ${ }^{144}$.

Es éste, indudablemente, el clima propio de una comedia de Lope de Vega. Pero si Betagh es sensible a lo novelesco de este clima, registra también, con su sano sentido común, lo que hay en él de práctico y confortable, sin preocuparse por lo que hublera de hipocresía :

These things are all done with the greatest gravity imaginable; and thus the practice of love becomes decent, safe and easy : so that a man may posses his mistress without any visible inconvenience, and spend all the money he has in the world without fear of brawls, duels, or $\alpha^{-}$roundhouse $e^{1 * 5}$.

Y a continuación opone estos usos y concepción del amor a las costumbres de clertas metrópolis "nórdicas":

not like the rude hectoring blades and prentices of a certain northern metropolis who are continually affronting the female sex, with shocking words or scandalous actions ${ }^{148}$.

Nos cuenta el caso de una mujer que, a pesar de este clima del amor "so regularly settled"h movida por losocelos, y sin mayores pruebas de sus sospechas ( $a$ propósito de lo cual Betagh cita las siguientes palabras de Shakespeare: "Trifles light as air are to the jealous confirmations strong"), dio públicamente muerte a su amante, y fue llevada por ello a juicio :

and when every one expected she would be cast for her life, her judges gave it this turn, that it was no malice forethought, but excess of love that prompted her to the rash deed. Whereupon she was acquitted: but the nice casuists thought she should in honor have hangd her self. This instance shows how sacred a thing of love is there judged to be, tho' in a state of concubinage only ${ }^{147}$.

144.-Id. Id., p. 272.
146.-Id. Id., p. 273.
146.-Id. Id., p. 273.
147.-Id. Id., p. 274 
Y concluye luego con palabras que nos pueden parecer extraordinarias, por lo que suponen de reconocimiento del relativismo de la moral y de la inseguridad de los juicios éticos, puesto que la bondad o maldad de las acciones humanas depende de las diferentes costumbres y gobiernos :

And the moral good or evil of some actions are hard to be determined, while different governments have different customs ${ }^{\mathbf{1 4 8}}$.

Advirtamos también cómo hace depender de un factor humano y contingente la determinación moral de un acto, y no de principios trascendentes. Todo esto nos puede parecer hoy un lugar común, pero en su época, dentro de sus circunstancias de cultura y de historia, una tal actitud no era de ningún modo corriente, salvo en ciertos círculos de gente ilustrada. En Dampier hay a veces una disposición semejante, pero no olvidemos su vocación científica, y su afán de registrar hechos más bien que de calificarlos o de probar con ellos una tesis de carácter filosófico. Y, desde luego, ninguno de nuestros filibusteros, en principio, y como regla general, tenía el bagage cultural del cual disponían, por $\theta$ jemplo, Frézier o La Condamine, capaz de predisponerlos a la tolerancia y a la aceptación de la relatividad de los usos $\theta$ instituciones. Eran gente o bien imoral tes decir, conscientemente, confesamente situada en oposición a una cierta moral, cuya vigencia por ello mismo reconocían-, o relativamente amoral, (aunque esto más bien en la práctica, y sólo raramente en sus juicios). El único reparo que Betagh pone a tales formas sociales del amor no es tampoco moral - no las encuentra licenciosas, excesivas, antinaturales-, sino de carácter práctico, y relacionado con la buena marcha de los asuntos públicos y privados, pues los hombres que dedican tanto tiempo a sus quehaceres y preocupaciones galantes descuidan la administración de su hacienda y el ejercicio de sus funciones públicas. Y todavía nos dice, en otro pasaje, que muchas costumbres que podrían ser censuradas en Europa ("In our unequal gloomy regions"), son aquí puro efecto de la naturaleza, del clima. Volvemos a decir que difícilmente se halla en los autores que estudiamos una actitud semejante, y que es aún más in-

148.-Id. Id., p. 274. 
sólita en un viajero de su nacionalidad, pues los de ella se muestran, en general, menos abiertos y receptivos que los franceses. A veces nos ha hecho pensar el Montaigne.

Como conclusión de ese capítíulo Betagh nos ofrece estas líneas, en las cuales no sólo concede a los peruanos - los españoles peruanos- la situación más favorable, geográficamente, a la consecución de la felicidad terrestre, sino que además los justifica, y da como explicación de sus defeclos las virtudes mismas del clima y la abundancia y fertilidad de la tierra, y recomienda el Perú y Lima a quien quiera liberarse de los trabajos y cuidados de esta vida:

The sum of this chapter, I shall only observe that the Spantsh Peruvlans are better seated for the hapiness of this wirld, than any people I know. If they are indolent, their great affluence makes them so. If they are delicate, the kind serenity of the climate contributes greatly to it. Much husbandry and labour is needless, where the whole year is a fruitful spring. Indeed the Nigros and Indians do all the work; for a white face is exemption enough from all labour and care. In our unequal gloomy regions, many customs would be condemnd, which are there the pure affects of nature : for the night and day make a happy medium between cold and heal. Therefore, if the general bent of human nature be for constant hapiness and freedom from pain, the man of pleasure musl go to Peru, and make Lima his temporal paradise ${ }^{148}$.

No hemos leido, ni volveremos a hacerlo en nuestro trabajo, palabras que como éstas celebren de tal modo la bondad del clima y la naturaleza entera de Lima, y que de esa manera sitúen en ella una suerte de correspondencia temporal y humana del paraiso.

\section{GEORGE ANSON}

El 18 de Septlembre de 1740 salió de una caleta inglesa una expedición de cinco naves y tres veleros pequeños dirigida contra las colonias españolas de América, a las órdenes de George Anson (1697-1762). En las inmediaciones del cabo de Hornos la

149.-Id. Id., p. 278-279. 
pequeña escuadra fue en gran parte dispersada por una gran tempestad. Uno de los buques, el "Wager", naufragó en el estrecho de Le Maire, y las extraordinarias aventuras de los sobrevivientes esián narradas en las relaciones de Cummings, Bulkeley y Morris, y sobre todo en la de Byron, cuya descripción de la tempesiad inspiró a Lord Byron, nieto suyo, la que aparece en su "Don Juan". Con sólo dos naves Anson llegó en el otoño de 1741 a las costas peruanas, capluró varias naves y saqueó Paita. Reducida luego a un solo barco, con el cual tomó el galeón del Tesoro de Acapulco, atravesó el Pacífico, y en 1744 llegó de retorno a Inglaterra, después de haber dado la vuelta al mundo. La historia de la expedición está narrada en "A Voyage round the World in the years 1740, 1, 2, 3, 4, by George Anson... compiled from papers and others materials of the George Lord Anson, and published under his Direction by Richard Waller", Londres. De este Walter sólo sabemos que era capellán del buque del Almirante, y que probablemente contó con la colaboración de un tal Robins en la redacción del libro.

El autor encuentra extremadamente agradable el clima de la costa peruana, el cual hace placenteros el aire libre y la luz diurna:

I shall now therefore add, that in this climate every circunstance concurred, that could render the open air and daylight desirable. For in olher countries thes scorching heat of the Sun in summer renders the greater part of the day unapt either for labour or amusement; and the frequent rains are not less troublesome in the more temperate parts of the year ${ }^{150}$.

La ausencia del sol, que en este clima feliz es paradójicamente un blen, no hace al cielo obscuro, sino que lo torna en un "alegre clelo gris". El aire tampoco se obscurece, ni mengua melancólicamente la luz del día :

But in this happy climate the sun rarely appears : Not that the heavens have at any time a dark and gloomy look; but there is constantly a chearful grey sky, just sufficlent to screen the sun, and to mitigate the violence of its per-

160.-George ANSON, Op. Cit., p. 258. 
pendicular rays, without obscuring the air, or tinging the day-light with an unpleasant or, melancholy hue ${ }^{151}$.

Sin embargo, estas características climáticas, sorprendentes y únicas para el sentir del narrador, no nos dice que sean propicias y favorables para una existencia muelle y sensual, como acontece en otros lugares, sino más bien que

By this means all parts of the day are proper for labour or exercise abroad, nor is there wanting that refreshment and pleasing refrigeration of the air, which is sometimes produced in other climates by rains for here the same effect is brought about by the fresh breezes from the cooler regions to the Southward ${ }^{152}$.

Y. como muchos otros viajeros, hace responsable a los Andes de esta dichosa complexión del tiempo:

It is reasonable to suppose that this fortunate complexion of the heavens is principally owing to the neighbourhood of those vast hills, called the Andes, which running nearly parallel to the shore, and at a small distance from it, and extending themselves immensely higher than any other mountains upon the globe, form upon their sides and declivities of prodigious traet of country, where, according to the different approaches to the summit, all kinds of climates may atfall seasons of the year be found. These mountains, by intercepting great part of the eastern winds which generally blow over the Continent of South America, and by cooling that part of the air which forces its way over their tops, and by keeping besides a prodigous extent of the atmosphere perpetually cool by its contiguity to the snows with which they are covered; these hills, I say, by thus extending the influence of their frozen crests to the neighbouring coasts and seas of Peru, are doubtless the cause of the temperature and equability which constantly prevail there. For when we were advancend beyon the equinoctial, where these mountains left us, and had nothing to screen us to the eastward, but the highlands in the isthmus of Panama, which are but mole-hills to the Andes, we then soon found that in a short run we had totally changed our climate, passing in two or three days from the tem-

151. -Id. Id., p. 528.

152.-Id. Id., p. 258. 
perate air of Peru, to the sultry burning atmosphere of the West-Indies ${ }^{163}$.

Advirtamos los adjetivos con los cuales pondera la elevación y la inmensidad de los Andes. De su desembarco en Paita, no encontramos en la relación nada más que el relato del ataque y del saqueo, y ninguna observación sobre la ciudad, las casas. etc. No hay, pues, como digno de notarse, más que esa imagen de un clima feliz, templado y fresco en mitad del trópico, y cuya suavidad se debe, precisamente, a la desmesurada elevación de aquellas montañas.

\section{CONCLUSION}

Al comienzo de nuestro estudio hablábamos de nuestro propósito de averiguar de qué manera reaccionaron los autores de las relaciones que hemos examinado frente a ciertas realidades $\rightarrow$ l paisaje, el clima, la flora- y ciertos aspectos del Perú de entonces - la leyenda de nuestras riquezas, las costumbres, la condición de sus pobladores, nuestra historia antigua, etc. Hemos terminado ya el examen de nuestros textos. Es, pues, el momento de recapitular, y, en la. medidá en que ello sea posible, señalar algunas tendencias y línegs generales como conclusión de nuestra modesta investigación.

El sentimiento del paisaje, tal como lo entendemos nosotros, no existe en las relaciones que hemos estudiado. Quienes las escribleron no hallan en la naturaleza una correspondencla afectiva, tonal, de sus estados de ánimo. Tampoco suelen tener frente a ella una actitud contemplativa, ni la hacen objeto de un exotismo sentimental. No hay nada más alejado, ni más opuesto, por ejemplo, que la actitud de un Chateaubriend, o la de los misioneros jesuttas. La naturaleza no es más que el escenario, a menudo hostil, de una aventura, de un hecho.

$Y$, sin embargo, de alguna manera reaccionaban estos hombres frente al particular paisaje de la costa peruana, frente a la desnudez extraña y silenciosa de nuestras islas, frente a la vista de los Andes, que, a lo largo de todo nuestro litoral, veían alzarse

153.-Id. Id., p. 258-259 
azules y coronados de nieve en los días despsjados, y obscuros, cuando no cubiertos, en los días nublados.

El adjetiva que más constantemente acompaña a la mención del aspecto de nuestra costa es el de estéril. La idea que evoca es a menudo reforzada mediante una acumulacián de negaciones que se refiere a la ausencia de verdor, de agua, de leña y provisiones. Wafer dice que esta costa es "barren and desolate"; el narrador do "The World Encompassed" dice que es "very borren, without water and wood"; Shelvocke dice que "the country of itself is barren"; Dampier cuenta que en este "dry country" no ha visto "any green thing growing in the Mountaines neither yel in the valleys, except where here and there...". Desde luego que el adjetivo "barren", así como las referencias a la ausencia de verdor y provisiones y madera, guardan relación con necesidades que sus autores experimentaban con urgencia, y con la búsqueda de medios para satisfacerlas, mucho más que con una im. probable actitud sentimental o estética frente al paisaje. Sólo el adjetivo "desolate" corresponde a una reacción menos objetiva, y lo emplea Wafer, quien parece haber sido más sensible que los otros a la visión de la desnudez de la costa peruana. Hay quienes - entre ellos- oponen esta desnudez y esterilidad de los desiertos costeños a la fecundidad, verdor, placentera situación, de los pequeños valles queter medio d’ ellos ses abren. Recordemos el pasajo de Wafor que citamos a este respecto. La serie de negaciones - de verdor, de agua, de cuciqulier signo de vida- quo nos describían el desierto, se torna, entonces, en la enumeración acumulativa de los frutos que producen esos valles, de su agua, de sus poblaciones.

De las islas de Lobos, aparte de las informaciones puramente náuticas, nos dicen cosas semejantes. Cooke reitera la ausencia de todo verdor. Shelvocke añade a esto la informactón de que el suelo se hallaba tan "quemado", que parecía ceniza. Speilbergen las halla habitadas por aves de forma y tamaño "maravillosos".

Pero no se vaya a creer que una actitud semejante aparece sólo en la parte de sus diarios que trata de su pasaje a lo largo de nuestras costas y de sus ocasionales desembarcos. Con la misma objetividad y sequedad reaccionan frente a otros paisajes, con algunos excepcionales acentos que no desmienten la tónica general. Aunque quizás quienes estuvieron en esas otras regiones 
describen con más calma y complacencia la exótica opulencia da las islas océanicas o de las costas asióticas.

En cuanto a los Andes, hay que distinguir las apreciaciones que se refieren a los cerros de la costa, de aquéllas que se refieren propiamente a la cordillera. De los costeños tambión nos dicen que son estériles, desnudos, grises. No se diferencian mayormente de la llanura desértica. Shelvocke habla de "Sandy mountains, perpetually parch'd by the hest of the sun" $y$ nos dice tanbién que a todo lo largo de nuestro litoral "there are lofty precipices, and large rocks near the sea", a los cuales el guano hace aparecer, a la distancia, como "chalk-eliffs".

A la Cordillera se refieren, sobre todo, insistiendo en la idea de su exiremada altura. Dampier nos dice que son "of a prodigious height", supone que son las montañas más altas de la tíerra, y advierte que sobrepasan, con mucho, la altura del Pico de Tenerife, tenido por eniances como uno de los mús altos del globo. Es el único en contarnos que esgs cumbres aparecen azules cuarido se las ve desde el mor, pero es ésła una comprobación puramente objetiva; no hay en ella ninguna intención "pasajista". afectiva. Funnell también nos dice que son "prodigious high", y que son, también "the highest land l ever saw". Anson afirma que son "immensely higher than cmy other mountains upon the globe". Rogers las compara también con el fico de Tenerife, $\mathrm{y}$ dice que se les ve "tout le long de cette route, avec le sommet couvert de nelge". Ringrose cuenlargue ldg Givbesi 6 ampidienon ver la cima de esas montañas. Betagh, curiosamente, no habla de los Andes - de sus cimas nevadas - sino para explicar el clima de la costa, a pesar de que fue él, entre todos, quien más oportunidgd tuvo de observar nuesira geogralía de cerca. Ellis, que vició a Huamanga y al Cuzco, no nos dice casi nada del paisaje y de la geografía, como si no le hubieran impresionado mayormente, o los hubiera dado como ya conocidos - al menos, es lo que aparece de la breve versión consignada por Purchas.

Dampler, Anson, Betagh y otros, hacen responsable, en cierta forma, a esa excesiva altitud, del clima de la costa, de su falta de Iluvias. Anson, aludiendo a estas dos circunstancias, partleularísimas y únicas en semejantes latitudes, nos habla de un "happy climate", de una "fortunate complexion" del mismo. Betagh nos dice que los vapores que nublan el cielo de Lima son una exhalaclón intermedia entre la bruma densa y baja de Euro- 
pa y sus nubes de verano, lo cual es "a happy convenience at Lima", que está así protegida del ardor del sol. Atribuye a la "kind serenity of the climate" la condición delicada de los limeños, y opone tácitamente este lugar, en donde "the whole year is a fruitful spring" - lo cual hace menos imperioso el trabajo-, a sus "gloomy regions" nativas. La naturaleza es responsable, además, de las particulares costumbres que ha observado en $\mathrm{Li}$ ma, "for the night and day make a happy medium between cold heat". Sharp comprueba la ausencia de lluvia, pero nos dice que en estos parajes cae un rocío tan fuerte, que con él los pequeños valles de la costa devienen muy fértiles, y producen tan buenas cosas como Inglaterra, y, además, vino.

$\mathrm{Si}$ añadimos a estos testimonios elogiosos la ausencia de otros desfavorables, podemos concluir, pues, que en general, encontraron el clima de nuestro litoral excelente, pues juntaba la suavidad de la temperatura, la ausencia de trastornos atmosféricos, la estabilidad. No estaba lejos de ese clima ideal que describían algunas narraciones de viajes imaginarios del Renacimiento, y ya de hecho Betagh lo mencionaba como una razón poderosa para que "the man of pleasure" estableciese aquí su paraíso terrenal. Si nosotros nos imaginamos que este templado clima estaba entre las tempestades e inmensidad desconocida de los mares australes, y los calores insufribles del mar tropical, estaremos más cerca de su punto de vista.

En cuanto al clima de las altas montañas," no tenemos sino la escueta referencia de Ellis, que nos habla del extremado frío que hacía ellas.

De los animales que pueblan esas dos regiones -la costa y la sierra-, nos describen sobre todo la llama. Evocan la gracia y majestad de su marcha, su resistencia, su conformación y tamaño, y la comparan a otros animales del Viejo Mund'o. No faltan también referencias teñidas de una graciosa credulidad. Hawkins nos habla de la chinchilla. Varios mencionan las aves guaneras y las islas donde anidan, cuyo desagradable olor no dejan de denostar. Los cóndores, en cambio brillan por su ausencia en todos estos relatos.

I. y F. Gall, en su documentado y agradable libro sobre "El Filibusterismo", nos hablan del mar como la entidad que confiere a los filibusteros su leyenda, como una potencia que ellos deben vencer, tornar en cómplice y aliado suyo, al mismo tiempo que 
es azar, es libertad. Y sin embargo, en estas relaciones de viaje, las que estudiamos aquí $\mathrm{y}$ otras que hemos consultado, no aparecen otras referencias que las estrictamente náuticas, es decir: mar agitado, mar tranquilo, mar lempestuoso. Estos hombres que se pasaban la mayor parte de su vida sobre frágiles buques, a los que confiaban su existencia y su fortuna, no muestran en sus libros ninguna sensibilidad, ninguna particular actitud afectiva, ninguna intimidad con el mar. Buscamos en vano adjetivos como los que en la Odisea, o en la llíada, nos califican las alternadas y extrañas variaciones de su color: mar negro, mar purpúreo, mar rojo. No hay adjetivos que describan el azul y el resplandor de los mares tropicales, escenario de sus mayores empresas, ni su oposición con el color obscuro de los mares australes. No encontramos tampoco ninguna muestra de ese horror elemental, primigenio, que de alguna manera sobrecoge al hombre frente al océano (con excepción, quizás, del horror que experimentó Shelvocke en esa caverna, sin duda situada a la orilla, en la Isla de Lobos).

Sería ocioso insistir en la afirmación de que entre aquellos corsarios existía, viva y renovada, una leyenda dorada del Perú. Era esa leyenda de riquezas una de las principales razones que los había movido a desplazarse unos buenos miles de kilómetros hasta el Mar del Sur. Buena parle de los tesoros de los que se apoderaron en Portobelo y Panamá provenían del Perú. Y sin duda nunca se olvidaron de aquellos galeones fábulosos como el "Cacafuego", que capturó "Drake" el l"Rosario", que procuraron a quienes se apropiaron de ellos una fortuna y gloria legendarias. La riqueza del Perú se da por sobreentendida. Hemos visto, sin embargo, algunos testimonios expresos suficientemente elocuentes. Françols Froger, en el diario de la expedición de $M$. de Gennes, que no pudo llegar hasta nuestras coslas, adonde venía con la intención de apresar naves y saquear puertos, nos dice: "Quol que nous n'ayons pas été assez heureux pour vois ces côtes fortunées du Pérou, d'où l'on tire ce que nous avons de plus précieux... ${ }^{154}$ Raveneau de Lussan nos advierte en un pasaje particularmente expresivo: "Avant de quitter cetłe Côle je ne puis me dispenser de dire que le Pérou est un des plus tiches pais du monde, non seulement par la quantité d'or et d'argent que les Espagnols tirent des mines qu'ils y possedent; mais de plus par la grande fecondité

154.-François FROGER, "Rélation d'un voyage de la Mer du Sud", Austerdam, 1715. 
de la terre qui rende a ceux qui la cultivent trois recoltes par chacune année...". En otro lugar también nos cuenta cómo en este reino se hacía de plata muchas cosas que en Europa eran de hierro, y cómo los filibusteros desdeñaban este metal por el oro que encontraban en sus presas. Anson nos dice, con una reticencia que no desmiente aquel prestigio. "... and in the neighbourhood of a country renowned for the abundance of its wealth, through it is at the same time stigmatised for its poverty in the necessaries and conveniences of a civilized life...". Rogers, hablando de la opresión y de la desorganización del imperio español en el Perú, concluye: "en sorte que, s'il avoit ici un Peuple industrieux, gouverné par de bonnes Loix, il est a craindre que l'Or \& l'Argent no clevinssent si communs, qu'ón sercit bientot obligé de recourir a quelque autre moien pour satisfaire l'avarice \& l'intemperance de hommes". Y todavía, en otro pasaje, asociando esos dos estados de una riqueza incalculabley de una desmesurada opresión: "Mais je ne crois pas qu'il y ait aucun Pays au Monde si riche, ni aucun Peuple sí cruellement opprimé que celui-ci". Betagh, hablando del recibimiento que Lima tributó al Duque de la Palata, cuando se cubrió una calle con barras de plata, compara esta magnificencia al esplendor de la Jerusalén salomónica.

La mención de las riquezas del Perú es asociada, en varios diarios, a la noticia del excesivo lujo $a$ que eran inclinados los peruanos -es decir los criollos y españoles. y muy particularmente las limeñas e"Of all parts of the World, the people are here most expensive in their habits" (Betagh).

La indole de sus expediciones, sus objetivos, sus circunstancias personales, explican, sin duda, el silencio que la mayor parte de nuestros autores guardan sobre el Perú pre-colombino. Apenas si hallamos en Wafer la consignación del testimonio de un indio viejo de Huarmey, el cual les dijo que en tiempos de sus padres los campos vecinos, ahora estériles, estaban muy bien cultivados y poblados, $y$ que eran tom numerosos sus pobladores que podían haber llevado un pez del mar hasta las manos del Inca, veinte leguas tlerra adentro, con sólo ponerse en fila y dárselo el uno al otro. Aún más, que cuando los españoles llegaron, aquéllos, antes que quedar a merced de los conquistadores, cavaron huecos y se enterraron vivos en ellos. Wafer inserta estas informaciones sin ningún comentario. Cooke glosa en los capítulos XVII y XVIII de su libro dos informes de las crónicas de Garcilaso. 
Herrera, Cieza y otros, y ofrece algunas noticias sobre el Perú de los Incas, sobre su gobierno, religión, costumbres, conquistas. El origen de estas informaciones concede a la adjetivación que usa entonces un valor sólo circunstancial, relativo. Ellis, quien estuvo en el Cuzco y Huamanga, apenas si nos dice, en la versión que aparece en Purchas, que próximo a la primera había un castillo "builded with stones of twentis tuns weight strangely joyned without morter". Betagh, por su parte, prefiere extenderse frivolamente sobre los usos galantes en Lima, y no nos da mayor noticia sobre la civilización prehispánica, con excepción de esta fugaz, alusión: "The want of rain in this part of the continent obliged the poor, I should say happy Indians, before the conquest..." Hay aquí, es verdad, una reminiscencia de la leyenda de una edad de oro, feliz y abundosa, del Incario.

Hemos encontrado pocas referencias a la situación de los indios, pero en ellas se advierte un sentimiento de compasión. La mayor parte de estos piratas trataba de utilizar en su favor el odio que los indios profesaban a los españoles. La expedición de Speilbergen contaba con él para promover un levantamiento, el cual habría hecho más fácil el quebrantamiento del poder español en esta parte de América. Betagh, acabamos de verlo, se refiere a su feliz situación "before the conquest", y en otros pasajes nos habla de la explotación a la que estaban sometidos, y de las ventajas y privilegios que procuraba el solo hecho de tener " $a$ white face" Hawkins también manifiesta compasión por el estado en que se encontraban. El narrador de "The World Encompassed" los compara a los escitas por la rectitud de su conducta, en oposición a los españoles, y dice que así como los griegos excedían (a los escitas) en conocimientos, les eran inferiores en principios morales $y$ rectitud de vida.

En cuanto a las costumbres - las de los españoles y criollos-, cuando hablan de ellas, las consideran con cierta tolerancia. Recordemos lo que nos decían Anson y Betagh al respecto. Atestiguan que había un clima bastante licencioso - nos cuentan sobre todo la relajación en que vivían frailes y monjas-, aunque luego lo atribuyen, en buena parte, al clima y bondad del suelo.

Todos los testimonios que hay al respecto estón acordes en ponderar la belleza de las mujeres peruanas, y particularmente de las limeñas -es decir, las españolas y criollas, pues a las indias no las tomaban en cuenta. Hemos visto los entusiastas elo- 
gios que Betagh les prodiga. Raveneau de Lussan se muesira no menos admirativo.

RELACIONES DE NAVEGANTES QUE ACASO EFECTUARON RECORRIDOS A LO LARGO DE NUESTRO LITORAL, DE LAS CUALES TENEMOS NOTICIA, PERO QUE NO NOS HAN SIDO ACCESIBLES

1.-Burney, en el vol. III, Cap. XIV, de su "A Chronological History of the Voyages and discoveries in the South Sea or Pacific Ocean", nos cita el diario de un tal Thomas Peche, del cual a su vez ha tenido noticia en el "Teatro Naval Hidrográfico", de Seixas y Lovera, Cap. $\mathrm{XI}$ (del cual sólo hemos podido consultar, sin hallar nada al respecto, una traducción francesa de 1704). Dice, pues, Burney: "The voyage next to be noticed has the apearance of romance, and it is probable that it is so in part; but here is reason for believing the circumstances related of the navigation are founded in fact". $\mathrm{Y}$ luego traduce el testimonio de Seixas y Lovera, el cual describe a aquel Thomas Peche como un inglés de gran experiencia náutica y conocimientos de cosmografia, el cual, después de doce años de piraterías y comercio en las Indias Occidentales, regresó a Inglaterra. Aqui, con otros, equipó un buque en 1673, y se dirigió por el estrecho de Le Maire a comerciar en las Filipinas y las Molucas. De estos lugares consideró que podía regresar más pronto a Inglaterra por el estrecho de Amián, pero los vientos lo obligaron a retroceder, y navegó por un buen tiempo a lo largo de las costas de California, Nueva España yeel Perú, y retornó al Mar del Norte, por Magallanes, en 1677. La relación, según Seixas, se imprimió en 1679, en inglés y francés, y nos afirma además, que vió a $\mathrm{Pe}$ che entre 1682 y 1684 en Holanda. En su vol. IV, p. 75, Burney nos dice: "and therefore his voyage to the South Sea is mentioned as a Bucaneer expedition; but it was in no manner connected with any enterprise in or from the West Indies. The only information we have of Peche's voyage is from an Spanish author, Seixas $y$ Lovera, and by that may be conjectured that Peche sciled to the Aleutian Isles". No los hemos nallado mencionado en ninguna otra bibliografía.

2.-Cox cita, como publicada en 1785 , una relación de la cual es autor John ROCH: "The surprising Adventures, of John Roch, Mariner, of Whitehaven; containing a genuine Account of his cruel Treatment during a long captivity amongst the Indians, and Imprisonemont by the Spaniards, in South America, with his miraculous Preservation and Delivrance by Divine Providence, and Happy Return to the Place of his Nativity, After being thirten Years amongst his inhuman Enemies", Liverpool. Ignoramos si esta relación tiene algo que ver con el Perú, pues nos ha sido inaccesible. 
3.-El mismo Cox cita "A Voyage to South America, describing at large the Spanish Cities, Towns, Provinces, etc., on that extensive Continent", 2 vols., Londres, 1772, relación de la cual es autor un tal John Adams. Ignoramos igualmente si trata del Perú, pues tampoco nos ha sido accesible.

\section{A D D EN D A}

La relación de la expedición de Clipperton que aparece en Callander, vol. III, pp. 444-502, contiene algunas fugaces referencias al Perú, pero que no nos han parecido de interés para nuestro trabajo.

De la expedición de Beauchesne-Gouin al Mar del Sur hay una relación o diario, escrito por "le Sieur de Villefort, enseigne du vaisseau...". En la recopilación de de Brosses figura un "abstract" del mismo, que hemos consultado, sin encontrar observaciones que nos pudieran haber sido de interés. En todo caso, el objetivo y desarrollo de esta expedición -que partió de Francia en 1698 y retornó en 1701 - no justificarian enteramente la inclusión de ese diario entre los que hemos examinado.

\section{BIBLIOGRAFIA CONSULTADA}

ANSON, George, "A voyage round the world in the years 1740, 1, 2, 3, $4, \ldots$ from papers and otther materials of the right Geoirge Lord Anson, and published under his Direction by Richard Walter", 3a. Dediciỏn, Londres, 1748.

ARBER, Edward, edicion de "A transcript of the Registers of the Company of Stationers of London", Privatelys Printed, Londres, 1875,5 vols.

ARCINIEGA, Rosa, "Pedro Sarmiento de Gamboa (el Ulises de América", Buenos Aires, 1956.

ARCINIEGAS, Germán, "Biografía del Caribe", Buenos Aires, 1957.

ATKINSON, Geoffroy, "Les Relations de Voyages du XVIIe siècle et l'évolution des idées. Contribution à l'étude de la formation de l'esprit du XVIIIe siècle", París s/f.

_- "Les Nouveaux Horizons de la Renaissance Française", Paris, 1935. re $1700 "$ ", Paris, 1922.

- "La Littérature géographique française de la Rénaissance: Répertoire bibliographique", París, 1927.

- "Supplément au Répertoire bibliographique se rapportant à la littérature géographique française de la Renaissance, París, 1936

BEAGLEHOLE, J. Capt., "The exploration in the Pacific", $2^{2}$ edición, Londres, 1947. 
BECKMANN, Johann, "Literatur der älteren Reisebeschreibungen", Göttingen, 1807-1809, 2 vols.

BENSON, E., F., "Sir Francis Drake", Londres, 1927.

BERVEILLER, "Mirages et visages du Pérou, Montrouge, 1959.

BETAGH, William, "A voyage round the World, being an account of a remarkable enterprize, begun in the year 1719 , chiefly to cruise on the Spaniards in the great South Ocean", Londres, 1728.

BOWEN, C. M., "Elizabethan Travel Literature", "Blackwood's Magazine", vol. 200, Octubre 1916, pp. 489-498, Edimburgo.

BROSSES, Charles de, "Histoire des navigations aux Terres Australes, contenant ce que l'on sait des moeurs et des productions des contrées découvertes jusqu'à ce jour", Paris, 1726, 2 vols.

BULKELEY, CUMMINGS, CAMPBELL, "Voyage à la Mer du Sud", Lyon, 1756.

BURNEY, James, Capt., "A Chronological History of the Voyages and discoveries in the South Sea or Pacific Ocean", Londres, 1803, 5 vols.

CALLANDER, John, "Terra Australis Cognita, or Voyages to the Terra Australis, or Southern Hemisphere, during the sixteenth centuries, containing an account of the manners of the people and the productions of the countries..., Edimburgo 1766-1768, 3 vols.

CAMUS, Armand Gaston, "Mémoire sur la Collection des Grands et Patits Voyages, et sur la collection des Voyages de Melchisedec Thevenot", Paris (1802).

CHINARD, Gilbert, "L'Amérique et le rêve exotique dans la littérature française du XVIIe et du XVIIIe siècle", Paris, 1913.

COX, Edward, "A Reference Guide to the literature of travel", Washington, $1935-1938,2$ vols.

COOKE, Edward, "A Voyage to the South Sea and round the world, perform'd in the years $1708,1709,1710$ and 1711 , containing a journal of all memorable transactions during the said voyage ... and a description of the American coasts", Londres, 1712, 2 vols.

CORBETT, Julian S., "Drake and the Tudor Navy, Whith the history of the rise of England as a maritime Power", Londres, 18951899, 2 vols.

DAMPIER, William, "A New Voyage round the world, describing particularly the isthmus of America, several coasts and islands in the West Indies, the isles of Cape Verd, the passage by Terra del Fuego, the South Sea coasts of Chili, Peru, and Mexico", Londres, 1697. 1699.

"A New Voyage round the World", $4^{\text {s }}$ edicion, Londres,

"Voyage de Guillaume Dampier aux Terres Australes, à Ia Nouvelle Hollande, etc., où l'on a joint, I Le voyage du ca- 
pitaine Wood à travers le détroit de Magallan, etc. II Le journal de l'expédition du Capitaine Sharp, III le Voyage autour du monde du Capitaine Cowley et IV le Voyage du Levant de M. Robert...", Tomo V, Amsterdam, 1712.

DECKER, Adolph, "Diurnal der nassawischen Flotta, oder Tageregis. ter und historische Beschreibungen...", Strassburg, 1629.

DRAKE, Sir, Francis, "The World encompassed... being his next voyage to that to Nombre de Dios formerly imprinted... collected out of the notes of Master Francis Fletcher", Londres, 1628.

"The World Encompassed"... with appendices... and introduction by W. S. W. Vaux, Londres, the Hakluyt Society, 1854.

FOSTER, William, "Purchas and his Pilgrims", en "Geographical Journal", vol. 68 , No 3, Septiembre de 1926.

GALL, J. y F., "El Filibusterismo", México, 1957.

GOSSE, Philip, "Histoire de la Piraterie, Paris, 1933.

HAKLUYT, Richard, "The principal Navigations, voiages, traffiques and discoveries of the English nation...", Londres, 1598, 3 tomos en 1 vol.

"The principal Navigations, voiages, traffiques and discoveries of the English nation...", Londres, 1599-1600, 2 vol.

"The principal Navigations, voiages, traffiques and discoveries of the English nation...", Londres, Hakluyt Society, 1903-1905, 12 vols.

HARTGERS, Ioost, "Oost-Indische Voyagien door die Begin en Voortgangh, van de Vereenighde Nederlandtsche Geoctroyeerde OostIndische Compagnie ."., Amsterdam, 1648.

HARING, C., H., "Los Bucaneros en las Indias Occidentales en el siglo XVII", Paris-Brujas, 1939.

HARRIS, John, "Navigantium atque itinarantium bibliotheca... to

- which is prefixed a copius introduction, comprehending the rise and progress of the art of navigation" ... revised... "and continued down to the present time" por J. Campbell, Londres, 1764, 2 vols.

HAWKINS, Sir Richard, "The Observations of Sir Richard Hawkins Knight, In His Voyage Into the South Sea", Londres, 1622.

en "The Hawkins Voyages during the reigns of Henri VIII, queen Elizabeth and James I", edición e introducción de CLEMENTS R. MARKHAN, Londres, Hakluyt Society, 1878.

HEAWOOD, Edward, "A History of Geographical Discovery in the Seventeenth and Eighteenth Centuries", Cambridge Geographical Series, Cambridge, 1912.

HOWARD, Clare, "English Travellers of the Renaissance", Londres, 1914. 
JOHNSON, Charles, Capt., "A general History of the Pyrates, from their first Rise and Settlements in the island of Providence, to the present time", Londres, 17.

JULIEN, Ch., $\mathrm{S}$., "Los Voyages de découverte et les premiers établissements - (XVe - XVIe siécles)", Paris, 1948.

L'HERMITE, Jacques, "Journeel vande nassausche Vloot, Ofte Beschryving vande Voyagie om den gantschen Aerdt-Kloot, ghedaen met elf Schepen...", Amsterdam, 1626.

LOW. Charles Rathbone, "Maritime Discovery. A history of nautical exploration from the earliest times", Londres, 1881, 2 vols.

MARKHAM, Clements R., "The Sea Fathers: a series of lives of Creat Navigators of Former Times", Londres, 1884.

MELO, Rosendo, "Los Piratas y el Callao antiguo; reseña históricomaritima del Sur-Pacifico, que comprende parte del siglo XVI, el siglo XVII y parte del siglo XVIII... [compaginada por....], Lima, 1893.

NOORT, Oliwier van, "Description du penible Voyage fait autour de l'Univers ou globe terrestre", Amsterdam, 1602.

NUN̄EZ, Estuardo, "Autores ingleses y norteamericanos en el Perú", Lima, 1956.

"El Perú y los escritores de viajes", Dominical de "La Crónica", 28 de Julio de 1957.

NUTTAL, Zelia, "New Light on Drake", Londres, Hakluyt Society, 1914. [ODRIOZOLA], "Relación de las excursiones de los piratas que infestaron la Mar del Sur en la época del Coloniaje", en ODRIOZOLA, Manuel, "Colección de documentos Jiterarios del Perú", Lima, 1863-1877, vol. II

OEXMELIN, Alexandre Olivier "Histoire des Aventuriers qui se sont signalés dans les Indes", Paris, 1762.

PALAU y DULCET, Antonio, "Manual del librero hispano-americano", Barcelona, 1923-1927, 7 vols.

PARKS, George Brunner, "Richard Hakluyt and the English Voyages", American Geographical Society, Publicacion No 10. Nueva York, 1028.

PERALTA, Manuel, "Costa Rica, Nicaragua y Panamá en el siglo XVI". Madrid-Paris, 1883.

PORRAS BAKRENECHEA, Raúl, "Los Viajeros italianos en el Perú". Lima, 1957.

-... "Fuentes Históricas Peruanas", Lima, 1955.

- Prólogo a "Dos Viajeros franceses del Perú republicano", Lima, 1847.

QUERARD, Joseph, "La France littéraire ou Dictionnaire bibliographique des savants, historiens, et gens de lettres de la France, ainsi que des littérateurs étrangers, qui ont écrit en français, plus particulièrement pendant les XVIIIe et XIXe siècles", $\mathrm{Pa}$ ris, $1827-1839,10$ vols. 
PURCHAS, Samuel, "Hakluytus posthumus, or Purchas, his Pilgrimes, containing a history of the world in sea voyages and land travellers by Englishmen and others...", Londres, 1625-1636, 5 vols.

- - "Hakluytus posthumus, or Purchas, his Pilgrimes, containing a history of the world in sea voyages and land traveHers by Englishmen and others...", Glasgow, Hakluyt Society, 1905-1907, 20 vols.

RAIMONDI, Antonio, "El Perú", Tomos I, II y III. Lima, 1876.

RAVENAU de LUSSAN, "Journal du Voyage fait à la Mer du Sud avec los Flibustiers de l'Amérique", París, 1689.

RAY, John Arthur, "Drake dans la poésie espagnole (1570-1732). Thèse de doctorat, Paris, 1906.

RENNEVILLE, René Augustin Constantin, "Recueil des Voyages qui ont servi à l'ètablissement et aux progrez de la Compagne des Indes Orientales, formée dans les Provinces-Unis des Pays Bas", Amsterdam, 1702, 5 vols.

RINGROSE, Basil, "The dangerous voyage and bold attempts of Capt. Barth. Sharp, Watlin, Sawkins, Coxon, end others, in the South Sea", en OEXMELIN, "The History of the bucaniers of America", vol. II, Londres, 1699.

RIVA-AGƯERO, José de la, "Historia del Perú", tomo I, Lima, 1953.

ROBERTSON, John, W., "Francis Drake and other early explorers along the Pacific Coast", San Francisco, 1927.

ROGERS, Woodes, "Voyage autour du monde, commencé en 1708 et fini en 1711", Amsterdam, 1716, 2 vols.

RUSSELL, W. Clark., "Life of'William Dampier", Londres, 1889.

SABIN, Joseph, "Dictionary of Books relating to America", New York, 20 vols.

SEIXAS y LOVEIRA, "Téathre Naval Hidrographique", Paris, 1704.

SHELVOCKE, George, "A Voyage round the World by the Way of the Great South Sea, performed in the years $1719,20,21,22$, in the Spidwell of London", Londres, 1723.

SPEILBERGEN, Joris van, "The East \& West Indian Mirror, being an account...", traducción, introducción y notas de J. de Villiers, Londres, the Hakluyt Society, 1906.

STEPHEN, Leslie, editor del "DICTIONARY OF NATIONAL BIOGRAPHY", Londres-Nueva York, 1885-1921, suplementos hasta 1930, 63 vols.

TIELE, Pieter Anton, "Mémoire bibliographique sur les Journaux des Navigateurs Néerlandais réimprimés dans les collections de de Bry et Hulsius...", Amsterdam, 1867.

WAFER, Lionel, "A New Voyage and Description of the Isthmus of America", Oxford, the Hakluyt Society, 1934.

WAGNER, Henry, "Sir Francis Drake's Voyage around the world; its aims and achievements...", San Francisco, 1926.

WIESSE, María, "El Mar v los Piratas", Lima, 1947. 